\title{
Signaling by FGF Receptor 2, Not FGF Receptor 1, Regulates Myelin Thickness through Activation of ERK1/2-MAPK, Which Promotes mTORC1 Activity in an Akt-Independent
} Manner

\author{
Miki Furusho, Akihiro Ishii, and Rashmi Bansal \\ Department of Neuroscience, University of Connecticut Medical School, Farmington, Connecticut 06030
}

FGF signaling has emerged as a significant "late-stage" regulator of myelin thickness in the CNS, independent of oligodendrocyte differentiation. Therefore, it is critically important to identify the specific FGF receptor type and its downstream signaling molecules in oligodendrocytes to obtain better insights into the regulatory mechanisms of myelin growth. Here, we show that FGF receptor type 2 (FGFR2) is highly enriched at the paranodal loops of myelin. Conditional ablation of this receptor-type, but not FGF receptor type 1 (FGFR1), resulted in attenuation of myelin growth, expression of major myelin genes, key transcription factor Myrf and extracellular signal-regulated protein kinase 1 and 2 (ERK1/2) activity. This was rescued by upregulating ERK1/2 activity in these mice, strongly suggesting that ERK1/2 are key transducers of FGFR2 signals for myelin growth. However, given that the PI3K/Akt/mechanistic target of rapamycin (mTOR) pathway is also known to regulate myelin thickness, we examined FGFR2-deficient mice for the expression of key signaling molecules in this pathway. A significant downregulation of p-mTOR, p-Raptor, and p-S6RP was observed, which was restored to normal by elevating ERK1/2 activity in these mice. Similar downregulation of these molecules was observed in ERK1/2 knock-out mice. Interestingly, since p-Akt levels remained largely unchanged in these mice, it suggests a mechanism of mTORC 1 activation by ERK1/2 in an Akt-independent manner in oligodendrocytes. Taken together, these data support a model in which FGFs, possibly from axons, activate FGFR2 in the oligodendrocyte/myelin compartment to increase ERK1/2 activation, which ultimately targets Myrf, as well as converges with the PI3K/Akt/mTOR pathway at the level of mTORC1, working together to drive the growth of the myelin sheath, thus increasing myelin thickness.

Key words: myelin; oligodendrocyte

Significance Statement

It is well accepted that myelin is a biologically active membrane in active communication with the axons. However, the axonal signals, the receptors on myelin, and the integration of intracellular signaling pathways emanating downstream from these receptors that drive the growth of the myelin sheath remain poorly understood in the CNS. This study brings up the intriguing possibility that FGF receptor 2, in the oligodendrocyte/myelin compartment, may be one such signal. Importantly, it provides compelling evidence linking FGFR2 with the ERK1/2-MAPK pathway, which converges with the PI3K/Akt/mTOR (mechanistic target of rapamycin) pathway at the level of mTORC1 and also regulates the transcription factor Myrf, together providing a mechanistic framework for regulating both the transcriptional and translational machinery required for the proper growth of the myelin sheath.

\section{Introduction}

Myelin produced by oligodendrocytes is a biologically active multilamellar sheath that wraps around axons, receiving and pro- cessing signals in bidirectional communication with axons (Bozzali and Wrabetz 2004; Nave 2010; Piaton et al., 2010; Simons and Nave 2015). It is essential for the rapid conduction of nerve im- 
pulses, and damage of this sheath, as in multiple sclerosis, leads to severe neurological deficits.

Previous genetic gain- or loss-of-function studies have implicated several extracellular growth factors or their receptor tyrosine kinases [such as insulin-like growth factor-1 (IGF-1), brain-derived neurotrophic factor, NT3, neuregulin-1-type III] in the regulation of CNS myelination (Carson et al., 1993; Cellerino et al., 1997; Kahn et al., 1999; Ye et al., 2002; Roy et al., 2007; Zeger et al., 2007; Brinkmann et al., 2008; D'Ercole and Ye, 2008; Taveggia et al., 2008; Vondran et al., 2010; Wong et al., 2013). Fibroblast growth factors (FGFs) and their four receptors (FGFR1-FGFR4) are also important extracellular signals that are known to regulate a variety of functions during development and in the adult (Dono, 2003; Brewer et al., 2016). Oligodendrocyte lineage cells express FGF receptors and coreceptors (heparan sulfate proteoglycans) in a developmentally regulated manner (Bansal et al., 1996a,b; Fortin et al., 2005). Both FGFR1 and FGFR2 are expressed in mature oligodendrocytes. Recently, through the analysis of conditional Fgfr1/Fgfr2 double knock-out mice, we showed that FGF signaling in oligodendrocytes plays a critical role in the postnatal CNS, where it regulates myelin thickness, independent of oligodendrocyte differentiation, and initiation of myelination (Furusho et al., 2012), and also in the adult CNS, where it promotes remyelination of chronically demyelinated lesions (Furusho et al., 2015).

FGFRs are known to recruit multiple downstream signaling pathways, including the Ras/Raf/Mek/Erk-MAPK and the PI3K/ Akt/mechanistic target of rapamycin (mTOR) pathways (Rubinfeld and Seger, 2005; Turner and Grose, 2010). A prominent role of the PI3K/Akt/mTOR pathways has been proposed in the regulation of oligodendrocyte differentiation and myelin growth in vivo (Narayanan et al., 2009; Goebbels et al., 2010; Harrington et al., 2010; Guardiola-Diaz et al., 2012; Bercury et al., 2014; Dai et al., 2014; Lebrun-Julien et al., 2014; Wahl et al., 2014; Zou et al., 2014). We proposed previously an equally important in vivo role of extracellular signal-regulated protein kinases 1 and 2 (ERK1/ 2 ), downstream mediators of the mitogen-activated protein kinase (MAPK) pathway, in the regulation of myelin thickness during developmental myelination (Ishii et al., 2012; Ishii et al., 2013). Furthermore, we have shown that FGFR and ERK-MAPK signaling continues to be required in oligodendrocytes throughout adulthood for the long-term growth and maintenance of myelin and for the support of axonal integrity (Ishii et al., 2014). In addition, when ERK1/2 are activated in preexisting mature oligodendrocytes during adulthood, new myelin growth can be reinitiated, even after active myelination is terminated, which has important implications for understanding the mechanism underlying the plasticity of myelin in adult life (Ishii et al., 2016; Jeffries et al., 2016).

Despite accumulating evidence implicating numerous extracellular signals and intracellular signal transduction molecules, a sequence of connected molecular events critical for receiving and processing extracellular information leading to the regulation of myelin thickness during developmental myelination has not been fully defined in the CNS. Here, we make use of a series of conditional genetically modified mice to address these issues and present a tentative scheme of events that highlights the role of FGF signaling in orchestrating the flow of information, potentially transmitted from the axon and received by FGFR2, a specific receptor type that transduces its signals downstream through the activation of ERK1/2, which propagates it further by converging with the $\mathrm{PI} 3 \mathrm{~K} / \mathrm{Akt} / \mathrm{mTOR}$ pathway at the level of $\mathrm{mTORC} 1$ and by regulating a master transcription factor, Myrf, together providing a means of regulating transcription and translation of myelin proteins and lipid-synthesizing enzymes required for the assembly of the myelin sheath during developmental myelination.

\section{Materials and Methods}

Generation of Fgfr1/Fgfr2 double and Fgfr1 or Fgfr2 single conditional knock-out mice. We generated conditional double knock-out (dKO) mice of genotype Fgfr $1^{\text {flox/flox }} ; \mathrm{Fgfr}^{\text {flox/flox}} ; \mathrm{Cn}^{\text {cre/+ }}$ by mating Fgfr $1^{\text {flox/flox }}$; Fgfr $2^{\text {flox/flox }}$ (Pirvola et al., 2002; Yu et al., 2003) with Cnp cre/+ $_{\left(2^{\prime}, 3^{\prime}-\right.}$ cyclic nucleotide $3^{\prime}$-phosphohydrolase; Lappe-Siefke et al., 2003) mice to produce progeny with disruption of both Fgfrl and Fgfr2 genes in CNPexpressing oligodendrocyte-lineage cells as described previously (Kaga et al., 2006; Furusho et al., 2009, 2012; Wang et al., 2009; referred to as Fgfr1/Fgfr2 dKO). We also generated single knock-out mice of Fgfr1 (referred to as Fgfr1 $c K O$ ) and Fgfr2 (referred to as Fgfr2 cKO) by similar mating of the Fgfrl or Fgfr2 floxed mice with $C n p^{\text {cre/+ }}$ mice. Littermates of these mutants lacking Cre are referred to as "controls." The genetic background of the Fgfr flox/flox $; F g f r 2^{\text {flox/flox }}$ lines is $129 / \mathrm{Sv}$, and that of the $C n p^{\text {cre }}$ line is C57BL/6. The conditional loss of FGFR1 and FGFR2 was confirmed by PCR, immunoblotting, in situ hybridization, and analysis of reporter mice as described previously (Kaga et al., 2006; Furusho et al., 2009, 2012; Wang et al., 2009).

To genetically elevate ERK1/2 activity in FGFR2-deficient oligodendrocytes, we generated transgenic mice by appropriate mating of $\mathrm{Fg} f 2^{\text {flox/flox }}$; $\mathrm{Cn} \mathrm{cre}^{\mathrm{cr}++}$ or Fgfr $1^{\text {flox/flox }} ; \mathrm{Fg}_{\mathrm{f}} 2^{\text {flox/flox }} ; \mathrm{CNP}^{\text {cre/+ }}$ with Rosa26StopFl $\mathrm{Mek}^{\text {MekD,EGFP/+ }}$ mice to produce progeny where Cre-mediated excision of floxed STOP cassette leads to the expression of constitutively active Mek1 in mice that have disruption of either Fgfr2 genes (referred to as Fgfr2-KO;Mek/+) or both $\mathrm{Fg} f \mathrm{r} 1 / \mathrm{Fg} f \mathrm{r} 2$ (referred to as Fgfr1/Fgfr2-dKO;Mek/+) in CNP-expressing oligodendrocyte-lineage cells.

Generation of other lines of genetically modified mice used in this study have been described previously, specifically, double knock-out mice with disruption of ERK1/2 of genotype $C n p^{\mathrm{Cre} /+} ; E R K 1^{-1-}$; $E R K 2^{\text {flox/flox }}$ (referred to as ERK1/2 dKO; Ishii et al., 2012) and transgenic mice with constitutively active Mek1 in CNP-expressing oligodendrocytes of genotype $\mathrm{Cnp}^{\mathrm{Cre} /+} ; \mathrm{Rosa26StopFl}^{\text {MeklDD,EGFP/+ }}$ (referred to as CnpCre;Mek/+; Ishii et al., 2013, 2016).

The Fgfr1 ${ }^{\text {flox/flox }}$; Fgfr $2^{\text {flox/flox; }}$ CNP ${ }^{\text {Cre/+ }}$ mice perform normally on the rotarod test (Furusho et al., 2009). However, these mice showed prolongation of auditory brain stem response peak latency, indicative of slower nerve conduction (Wang et al., 2009). The Fgfr2 cKO mice appear to have a normal gait, but extensive behavior tests have not been carried out on these mice.

Immunolabeling and histology. As described previously (Kaga et al., 2006; Furusho et al., 2012; Ishii et al., 2012), postnatal day 15 (P15) and 2-month-old mice of both sexes perfused with PBS or 4\% paraformaldehyde/PBS were subjected to postfixation overnight in $4 \%$ paraformaldehyde/PBS, and then over another night in $20 \%$ sucrose/PBS. Cryostat transverse sections $(15 \mu \mathrm{m})$ of cervical spinal cord were cut. For myelin basic protein (MBP; 1:3000; Dr. E. Barbarese, UConn Health, Farmington, CT) immunolabeling, sections were delipidated with $100 \%$ ethanol for $10 \mathrm{~min}$, washed with PBS ( 3 times, 10 min each), and blocked $(1 \mathrm{~h})$ in PBS, $10 \%$ normal goat serum (NGS; Invitrogen), $5 \%$ BSA, and $0.1 \%$ fish gelatin. Before immunolabeling for phosphorylated ERK1/2 (p-ERK1/2; 1:400; Cell Signaling Technology), p-Akt (Thr308; 1:100; Cell Signaling Technology), p-Raptor (Ser696; 1:100; Millipore), p-p70S6K (Thr421/ 424; 1:50; Santa Cruz Biotechnology), FGF1 (1:50; Santa Cruz Biotechnology), FGF2 (1:50; Millipore), or Neurofilament H (NFH; 1:200; Sigma), spinal cord sections were subjected to antigen retrieval by $5 \mathrm{~min}$ of incubation at $95^{\circ} \mathrm{C}$ in citrate buffer, $\mathrm{pH} 6.0$, washed with PBS ( 3 times, 10 min each), and blocked ( $1 \mathrm{~h}$ ) in PBS, $10 \%$ NGS, and $0.03 \%$ Triton X-100. For p-mTOR (Ser2448; 1:100; Cell Signaling Technology) and p-S6RP (Ser235/236; 1:100; Cell Signaling Technology) immunolabeling, sections were incubated in TBSS and $5 \%$ methanol/ $1 \% \mathrm{H}_{2} \mathrm{O}_{2}$ for 10 min, washed with TBSS ( 3 times, 10 min each) and $10 \%$ Triton X-100 for $30 \mathrm{~min}$, and blocked ( $1 \mathrm{~h}$ ) in TBSS and 10\% NGS and then TBSS, $0.3 \%$ BSA, and 0.02\% Triton X-100. For FGFR2 (1:50; Santa Cruz Biotechnology) and FGFR1 (1:500; Cell Signaling Technology) immunolabeling, 
teased spinal cord axons were incubated in $0.1 \% \mathrm{H}_{2} \mathrm{O}_{2}$ for $30 \mathrm{~min}$, washed with PBS (3 times, 10 min each), and blocked (1 h) in PBS, $10 \%$ NGS, and 0.3\% Triton X-100. For Caspr (1:100; Neuromab) immunolabeling, the teased spinal cord axons were blocked $(1 \mathrm{~h})$ in PBS, $10 \%$ NGS, and $0.3 \%$ Triton $\mathrm{X}-100$. Specimens were incubated with primary antibody in blocking buffer at $4^{\circ} \mathrm{C}$ for $24-72 \mathrm{~h}$. Phosphate-buffered or Tris-buffered saline containing $100 \mu \mathrm{M}$ sodium fluoride and $100 \mu \mathrm{M}$ $\mathrm{o}$-vanadate were used for dilutions of antibodies and washes. After washing the primary antibody, the specimens were incubated in appropriate secondary antibodies conjugated to biotin (1:200; Vector Laboratories), Cy3 (1:500; Jackson ImmunoResearch), or Alexa Fluor 488 (1:500; Invitrogen), and nuclei were counterstained with Hoechst blue dye 33342 ( $1 \mathrm{mg} / \mathrm{ml}$; Sigma). The avidin/biotinylated enzyme complex system (Vector Laboratories) was used to detect biotinylated secondary antibodies, and the color was developed by incubation in 3,3'-diaminobenzidine (DAB; Sigma). Negative controls were treated identically except for the exclusion of primary antibodies. Quantification of the MBP immunolabeled area of white matter was done using the area measurement function in Photoshop. Images were taken from matched lateral-ventral white matter regions of cervical spinal cord in all cases.

In situ hybridization. Transverse sections of cervical spinal cord from P30 or 1.4-month-old mice were prepared as above, and in situ hybridization was performed as described previously (Furusho et al., 2011, 2012; Ishii et al., 2012) using riboprobes specific for proteolipid protein (PLP) mRNA (Dr. W. B. Macklin, University of Colorado School of Medicine, Aurora, CO) or MBP mRNA (Dr. M. Qiu, University of Louisville, Louisville, KY). Briefly, after incubation in $1 \mu \mathrm{g} / \mathrm{ml}$ proteinase $\mathrm{K}$ at $37^{\circ} \mathrm{C}$ for $30 \mathrm{~min}$, sections were hybridized overnight at $65^{\circ} \mathrm{C}$ with digoxigenin-labeled antisense cRNA probe and washed in $50 \%$ formamide, $2 \times \mathrm{SSC}$, and $1 \% \mathrm{SDS}$ at $65^{\circ} \mathrm{C}$ for $2-3 \mathrm{~h}$, followed by rinses in $2 \times$ SSC and $0.2 \times$ SSC at room temperature and $0.1 \times$ SSC at $60^{\circ} \mathrm{C}$. After blocking in $1 \%$ Tween 20 and $1 \%$ normal goat serum $(1 \mathrm{~h})$, sections were incubated (overnight) in alkaline phosphatase-conjugated antidigoxigenin antibody (1:2000; Roche). Color was developed with 4-nitroblue tetrazolium chloride and 5-bromo-4-chloro-3-indolylphosphate.

Electron microscopy. Five- to 7-month-old transgenic and littermate control mice of both sexes were perfused with $4 \%$ paraformaldehyde, $2 \%$ glutaraldehyde in $0.1 \mathrm{~m}$ cacodylate buffer, $\mathrm{pH} 7.4$ (Electron Microscopy Sciences). Cervical spinal cords of transgenic and littermate control mice were postfixed in $1 \% \mathrm{OsO}_{4}$. Samples were dehydrated through graded ethanol, stained en bloc with uranyl acetate, and embedded in Poly/ Bed812 resin (Polysciences). Thin $(1 \mu \mathrm{m})$ sections were stained with toluidine blue, and ultrathin $(0.1 \mu \mathrm{m})$ sections from matching areas of experimental and control tissue blocks were cut and visualized using an electron microscope (JEOL1200CX) at $80 \mathrm{kV}$. Digitized images (3000X magnification) were used to determine the g-ratios of randomly selected myelinated axons. Approximately 200-300 axons from two mice per genotype were measured per genotype from matched regions of the ventral cervical spinal cord. Statistical analysis was performed on average g-ratios using Student's $t$ test. For comparison of control and mutant mice, note that higher g-ratios indicate thinner myelin sheath.

Quantitative real-time PCR. Total RNA from spinal cords of P15 or 1.4month-old mice was extracted using the TRIzol reagent (Invitrogen). One microgram of total RNA was reverse transcribed to cDNA using the iScript Synthesis Kit (Bio-Rad) according to the manufacturer's instructions. Quantitative real-time PCR (qRT-PCR) was performed using an Eppendorf Mastercycler ep realplex Thermal Cycler or CFX Connect Real-Time PCR Detection System (Bio-Rad) and iQ SYBR Green Supermix (Bio-Rad) according to the manufacturer's instructions. qRT-PCR conditions were as follows: denaturation at $95^{\circ} \mathrm{C}, 30 \mathrm{~s}$; primer annealing at $55.5^{\circ} \mathrm{C}$ or $53^{\circ} \mathrm{C}, 30 \mathrm{~s}$; and elongation at $72^{\circ} \mathrm{C}, 40 \mathrm{~s}$. Quantification of PCR products was performed using the 2- $\Delta \Delta \mathrm{Ct}$ method. Quantities of mRNA were normalized to the housekeeping gene glyceraldehyde-3-phosphate dehydrogenase (GAPDH). The following primers were used: PLP forward primer, $5^{\prime}$-GTATAGG CAGTCTCTGCGCTGAT-3'; PLP reverse primer, 5'-AAGTGGCAGCAA TCATGAAGG-3'; MBP forward primer, 5'-TACCTGGCCACAGCAAG TAC-3'; MBP reverse primer, 5'-GTCACAATGTTCTTGAAG-3'; CGT (cerebroside galactosyl transferase) forward primer, $5^{\prime}$-CAGAGGC GCTCTCCAACTC-3'; CGT reverse primer, 5'-GCACTCCACAGG
AGCATGAA-3'; Fdft1 forward primer, 5'-GCCTGCCGTCAAAGC TATCATA-3', Fdft1 reverse primer, 5' -TCTTGGAGATGACCTGCT TGGT-3'; Myrf forward primer, 5' -TGGCAACTTCACCTACCACA-3', Myrf reverse primer, 5'-GTGGAACCTCTGCAAAAAGC-3'; Zfp191 forward primer, 5'-GCTCAGGGATTACCGAGTTC-3'; Zfp191 reverse primer, $5^{\prime}$-CTCTCCAGCTGAAGCCATCT- $3^{\prime} ; N k x 6.2$ forward primer, $5^{\prime}$ CTTTCTCGGTAGCTGACATTCTC-3'; Nkx 6.2 reverse primer, 5'-TC GCTGCTCTCAAACCATCC-3'; Olig1 forward primer, 5'-GACCTC AGCCAATCTTCC-3'; Olig1 reverse primer, 5'-TAACACCCTTGATGT TTGTACC-3'; Olig2 forward primer, 5' ${ }^{\prime}$ TTATTACAGACCGAGCCAA CACC-3'; Olig2 reverse primer, 5'-GTCGTGCATGCGCTTGCGTT-3'; Sox10 forward primer, 5'-AGCCCAGGTGAAGACAGAGA-3'; Sox10 reverse primer, 5'-AGTCAAACTGGGGTCGTGAG-3'; and YY1 forward primer, $5^{\prime}$-TTGAGCTCTCAACGAACGCTTTGC-3'; YY1 reverse primer, 5'-TCAGACCCTAAGCAACTGGCAGAA-3'; GAPDH forward primer, 5' TGTGTCCGTCGTGGATCTG-3'; GAPDH reverse primer, $5^{\prime}$-CA TGTAGGCCATGAGGTCCACCAC-3'.

Immunoblotting. Immunoblotting was performed as described previously (Fortin et al., 2005). Briefly, equal amounts of total proteins from lysates of white matter from spinal cords of P15 mice were loaded onto SDS-PAGE gels, transferred to PVDF membranes, and immunolabeled for anti-FGFR2, (1:50; Santa Cruz Biotechnology), phospho-ERK1/2 (1: 10,000; Cell Signaling Technology), phospho-mTOR ${ }^{2448}$ (1:1000; Cell Signaling Technology), p-Akt ${ }^{308}$ (1:1000; Cell Signaling Technology), and GAPDH (1:60,000; Biodesign International) as a loading control. Quantification of the bands was done by ImageJ software. Statistical analysis used to evaluate immunoblots was done by one-way ANOVA.

Myelin fractionation. Myelin was purified from adult mouse brains by sucrose density gradient centrifugation as described previously (Menon et al., 2003). Four fractions were collected, floating at different sucrose densities: "main band" (MB; 12.0-22.5\%), "dispersion" (22.5-25.4\%), "heavy band" (HB; 25.5-26.9\%), and "pellet." Total protein concentrations were determined by BCA protein assay (Bio-Rad).

\section{Results}

FGFR2 is enriched at the paranodal loops of myelin, and FGF1 and FGF2 are expressed by the axons

We showed previously that FGFR2 is the most abundant of the three FGFRs expressed in oligodendrocyte lineage cells. Its expression begins upon oligodendrocyte terminal differentiation, concomitant with the expression of major myelin proteins. FGFR1 is expressed both in oligodendrocyte progenitors and in differentiated oligodendrocytes, although to a lower extent. FGFR3 and FGFR4 are not expressed in differentiated oligodendrocytes (Bansal et al., 1996a; Fortin et al., 2005). Interestingly, immunoblotting of purified myelin showed that FGFR2, but not FGFR1, is also expressed in adult myelin (Fortin et al., 2005, Bryant et al., 2009). However, the subdomains of myelinated fiber where FGFR2 is localized in vivo are not known. Therefore, we immunolabeled teased fiber preparations from spinal cords with anti-FGFR2 (Fig. 1Aa). We found intense immunolabeling for FGFR2 in a pattern indicative of its localization at the paranodal region of myelin. Double immunolabeling of FGFR2 with Caspr, which marks the paranodal region, showed an overlapping pattern in control mice, providing further evidence that suggests an enrichment of FGFR2 at the paranodal region (Fig. 1Ab). As expected, FGFR2 immunolabeling was lost from the Caspr+ paranodal region in Fofrl/Fgfr2 $d K O$ mice (Fig. 1Ab). Since these FGFRs were conditionally ablated from oligodendrocytes in these mice, the loss of FGFR2 immunolabeling in the Fgfr1/Fgfr2 dKO mice indicates that the observed FGFR2 expression at the paranodes is in myelin and not in the axons. The specificity of the staining is further evident by the absence of signal with anti-FGFR1 or with the secondary antibodies alone at the Caspr+ paranodal region (Fig. 1Ac).

We next took an alternate biochemical approach to determine the localization of FGFR2 in myelin subdomains. This was done 


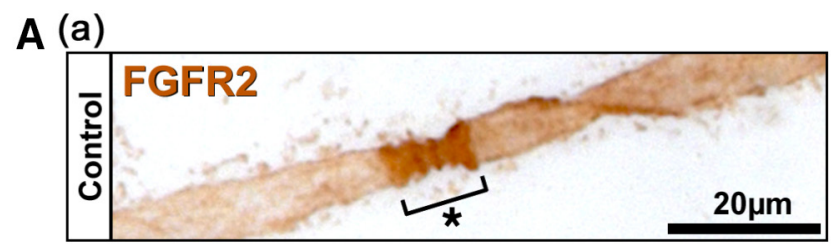

(b)

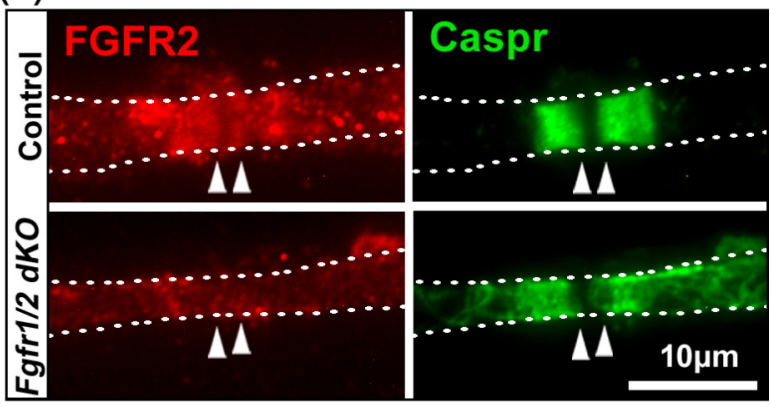

(c)

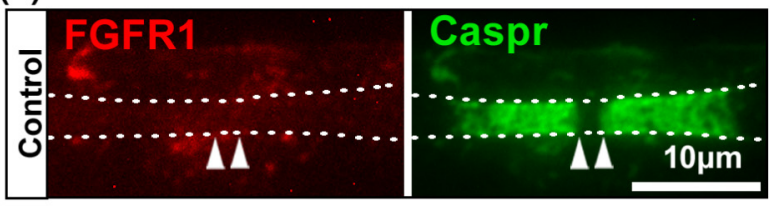

B (a)

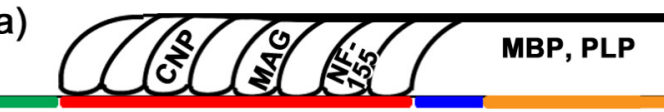

paranode Internode (b) (Non-compact myelin)

(compact

(High)

Sucrose density

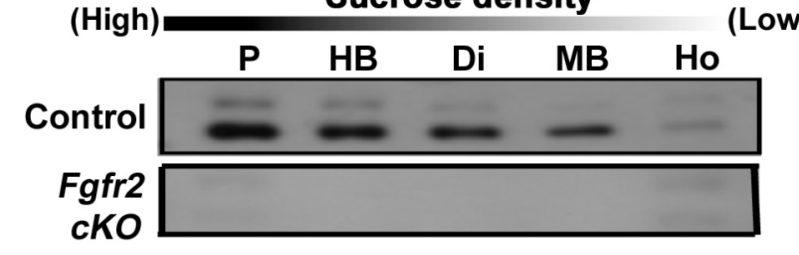

C
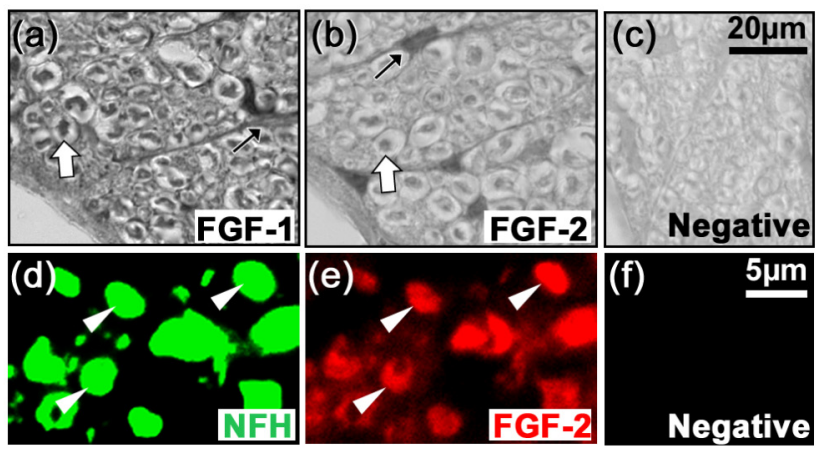

Figure 1. FGFR2 expression is enriched at the paranodal loops of myelin, and FGF1 and FGF2 are expressed by the axons. Aa, Immunolabeling of teased fiber preparations from spinal cords of 2-month-old control mice shows intense staining for FGFR2 in a pattern indicative of its enrichment at the paranodal region (asterisk) of the myelinated fiber. $\boldsymbol{A} \boldsymbol{b}$, Double immunolabeling shows that FGFR2 (red) is largely colocalized with the paranodal marker Caspr (green) and that its signal is lost in the Fgfr1/Fgfr2 dKO mice, demonstrating the specificity of this staining pattern for myelin (arrowheads mark the nodal region). Ac, Double immunolabeling shows that anti-FGFR1 or the secondary antibody alone (red) does not label the Caspr + (green) paranodal region of control mice. $\boldsymbol{B a}$, Schematic representation of subdomains of the myelinated fiber [node (green), paranode (red), juxtaparanode (blue), and internode (orange)] and example of the myelin proteins expressed in noncompact (CNP, MAG, NF-155) and compact by sucrose density fractionation of myelin purified from the brains of adult control and Fgfr2 $c K O$ mice as described previously (Menon et al., 2003). This method has been shown to "biochemically dissect" out the subdomains of myelin, such that the myelin proteins expressed in different subdomains distribute in a typical pattern of increased or decreased enrichment in the sucrose gradient, as shown diagrammatically in Figure $1, B a$ and $B b$ (adapted from Menon et al., 2003, their Fig. 8). For example, the myelin proteins like MBP and PLP, which are expressed in compact multilamellar myelin, are most enriched in lowsucrose-density fractions, while the myelin proteins like CNP, myelin-associated glycoprotein (MAG), and neurofascin-155 (NF-155), which are expressed in the cytoplasmic noncompact myelin, such as the paranodal and adaxonal regions, are most enriched in high-sucrose-density fractions. Immunoblotting of fractionated myelin from normal control mice showed that FGFR2 was most enriched in the high-sucrose-density fraction (HB) and lowest in the low-density fraction (MB; Fig. $1 \mathrm{Bb}$ ). This pattern of distribution is typical for other myelin proteins that are preferentially enriched in the cytoplasmic noncompact compartments (Menon et al., 2003). Furthermore, the FGFR2 signal was completely lost from all fractions of myelin purified from the Fgfr 2 cKO mice (Fig. $1 B b$ ), indicating that the FGFR2 signal was not from axons that might have contaminated the myelin fractions. Taken together, we conclude that FGFR2 is preferentially enriched at the cytoplasmic noncompacted regions of myelin, primarily at the paranodal loops. Nevertheless, it is likely that FGFR2 is also present in other cytoplasmic compartments of myelin, such as the adaxonal region, but may be below the limits of clear detection by immunostaining (Fig. $1 A$ ).

Given the presence of FGFR2 in purified myelin membranes and its enrichment at the paranodes in vivo, we hypothesized that if the ligand, FGF, was present in the axonal compartment, then FGFR2 in myelin could potentially receive and transmit these axonal FGF signals to the oligodendroglial compartment. We therefore asked if the two major FGFs, FGF1 and FGF2, could be detected in axons. We immunolabeled transverse spinal cord sections with anti-FGF1 and anti-FGF2 (Fig. 1C). Images of ventral white matter sections showed darkly stained regions surrounded by unstained whitish regions (white arrows) (Fig. $1 \mathrm{Ca}, \mathrm{Cb}$ ). Furthermore, when sequential sections were double immunolabeled for the axonal marker neurofilament-M (red) and the myelin marker MBP (green), we found a ring of green (myelin) surrounding the red (axon), indicating that the whitish lipid-rich ring of myelin sheath surrounds the darkly stained FGF1- or FGF2-positive axons (data not shown). This was further confirmed by double immunolabeling sections for the axonal marker NFH (green) and FGF2 (red) which showed an overlapping pat-

\footnotetext{
$\leftarrow$

myelin (MBP, PLP) that distribute in a typical pattern of relative enrichment when myelin is fractionated on a sucrose density gradient (adapted from Menon et al., 2003). Bb, Immunoblotting of fractionated myelin from normal control mice show that FGFR2 is most enriched at high and least enriched at low sucrose densities in a pattern of distribution typical for other noncompact myelin proteins, while FGFR2 is completely lost from all fractions of myelin in the Fgfr2 cKO mice. Ho, Homogenate; Di, dispersion; $\mathrm{P}$, pellet. Ca-Cf, Immunolabeling of spinal cord crosssections from control mice with anti-FGF1 (a) and anti-FGF2 (b) shows darkly stained regions surrounded by unstained ring-like region (white arrows) in the white matter. Anti-FGF1 and anti-FGF2 also immunolabel astrocyte-like cells (black arrows). Cervical spinal cord sections double-labeled for the axonal marker NFH ( $\boldsymbol{d}$, green) and anti-FGF2 (e, red) show overlapping labeling of axons (arrowheads). Negative controls are secondary antibodies alone $(\boldsymbol{c}, \boldsymbol{f})$. Representative images taken from similar regions of lateral-ventral white matter are shown. $N=3-4$ mice for each condition.
} 

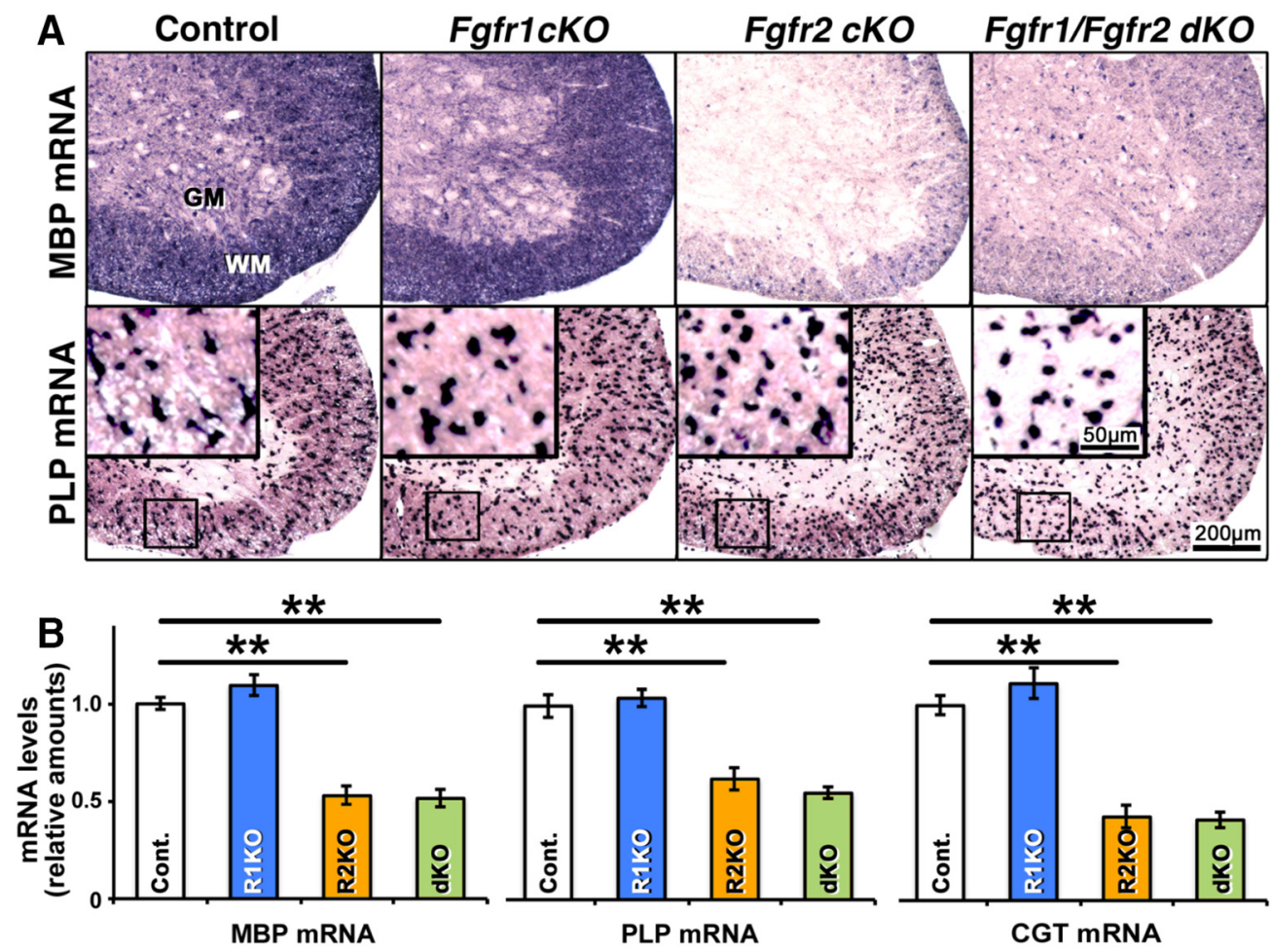

Figure 2. Myelin gene expression is reduced in mice lacking Fgfr 2 but not Fgfr 1.A, Transverse sections of cervical spinal cord at P30, analyzed by in situ hybridization for MBP and PLP mRNA from control, Fgfr1 CKO, Fgfr2 cKO, and Fgfr1/Fgfr2 dKO mice show reduced signal intensity for MBP mRNA in Fgfr2 cKO and Fgfr1/Fgfr2 dKO but not Fgfr1 cKO mice compared to controls. PLP mRNA signal also appears to be reduced in $F g f r 2 C K O$ and Fgfr1/Fgfr2 $\mathrm{dKO}$ but not Fgfr1 $\mathrm{CKO}$ oligodendrocytes compared to controls (inset shows cellular labeling at higher magnification). B, Quantification of mRNA levels by qRT-PCR in P15 spinal cords shows a significant reduction in the expression of MBP, PLP, and CGT mRNA levels in Fgfr2 CKO (R2KO) and Fgfr1/Fgfr2 dKO (dKO) but not Fgfr1 cKO (R1KO) mice compared to controls (cont.). Three to four mice of each group were analyzed. Error bars indicate SEM $(N=3-4)$. ${ }^{* *} p<0.01$. WM, White matter; GM, gray matter.

tern (Fig. $1 C d, C e$ ), indicating that FGF2 is expressed by axons. In addition, FGF1 and FGF2 were also detected in astrocytes (Fig. $1 \mathrm{Ca}, \mathrm{Cb}$, black arrows).

We conclude that axons express FGF1 and FGF2, while FGFR2 is expressed in noncompact cytoplasmic compartments of myelin preferentially enriched at the paranodal loops (and perhaps also at the adaxonal regions), providing a potential means of signaling between FGF and FGFR2 at the axon-glial interphase.

FGFR2 but not FGFR1 signaling in oligodendrocytes is required for the regulation of myelin gene expression and myelin thickness in the CNS

Our previous studies have shown that both FGFR1 and FGFR2 are expressed by mature oligodendrocytes in culture (Bansal et al., 1996b; Fortin et al., 2005; Bryant et al., 2009). Therefore, to determine the role of FGF signaling in oligodendrocytes during developmental myelination, we generated and examined the Fgfrl/Fgfr2 double knock-out mice and found reduced myelin gene expression and myelin thickness in these mice (Furusho et al., 2012). However, it is not clear from these studies whether FGFR1, FGFR2, or both are required to carry out this important regulatory function. Therefore, here, we generated and analyzed mice with conditional ablation of either Fgfr1 or Fgfr2. For comparison, we also analyzed the $F g f r 1 / F g f r 2 d K O$ mice in parallel.

We first examined the expression of MBP and PLP mRNA by in situ hybridization at $\mathrm{P} 30$ in the spinal cords of Fgfr $1 \mathrm{cKO}, \mathrm{Fgfr} 2$ $c K O, F g f r 1 / F g f r 2 d K O$, and littermate control mice (Fig. $2 A)$. The MBP mRNA signal intensity was dramatically reduced in Fgfr2 cKO but not in Fgfrl cKO mice compared to controls. The Fgfrl/ $\mathrm{Fgfr} 2 \mathrm{dKO}$ mice also showed a decrease, as we reported previously
(Furusho et al., 2012). Furthermore, the PLP mRNA signal also appeared to be reduced in the Fgfr $2 c K O$ and Fgfr $1 / F g f r 2 d K O$ but not in the Fgfrl cKO oligodendrocytes compared to control. Quantification of mRNA levels by qRT-PCR in P15 spinal cords showed a significant reduction in the expression of both $\mathrm{MBP}$ and PLP transcripts in the Fgfr $2 c K O$ compared to controls. This was comparable to the reduction in Fgfrl/Fgfr2 dKO. In contrast, the levels in Fgfr1 cKO mice were not reduced and were comparable to the levels in controls (Fig. $2 B$ ). We also found a significant reduction in CGT mRNA levels, a major glycolipid-synthesizing enzyme, in the spinal cords of Fgfr $2 \mathrm{cKO}$ and Fgfrl/Fgfr2 $d K O$ mice but not in Fgfrl cKO compared to control mice, indicating that both myelin proteins and lipids were affected by the loss of FGFR2 signaling.

We next examined the effect of ablation of either Fgfrl or Fgfr2 on myelin thickness. Analysis of EM micrographs at low and high magnifications showed that compared to control, the thickness of myelin was reduced in $\mathrm{Fgfr} 2 \mathrm{cKO}$ mice, and the reduction was similar to that seen in Fgfr $1 / F g f r 2 d K O$ mice. In contrast, in Fgfr 1 cKO, myelin thickness was not reduced and was comparable to control mice (Fig. 3A). Morphometric quantification of myelin thickness by g-ratio analysis (ratio of individual axon diameters to myelinated fiber diameters) from the ventral cervical spinal cord confirmed that compared to control, there was a significant reduction in myelin thickness (higher g-ratios indicate thinner myelin sheath) in Fgfr2 cKO and Fgfrl/Fgfr2 dKO mice but not in Fgfr1 cKO mice ( $p$ values for average g-ratios: control vs Fgfrl $c K O, p=0.86$; control vs Fgfr $2 c K O, p=1.6 \times 10^{-13}$; control vs $\left.F g f r 1 / F g f r 2 d K O, p=2.5 \times 10^{-33}\right)$. Similarly, when myelin thickness (in micrometers) was plotted as a function of axon diameter, it showed that while in the control and Fgfr $1 \mathrm{cKO}$ 
A

A Control
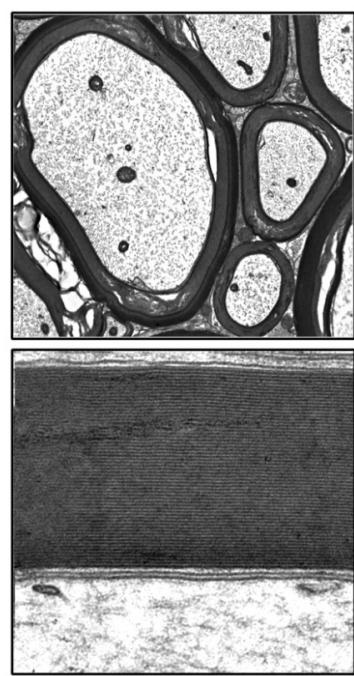

B

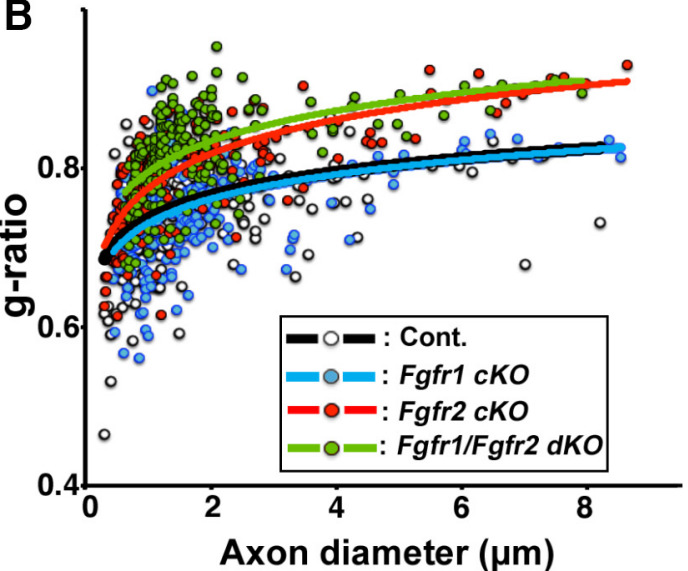

Fgfr1 cKO
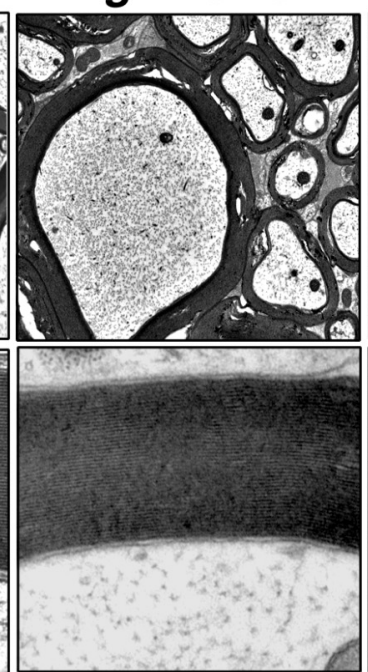

Fgfr2 cKO

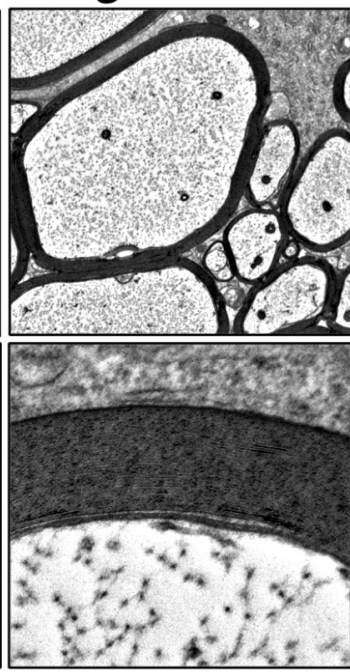

Fgfr1/Fgfr2 dKO
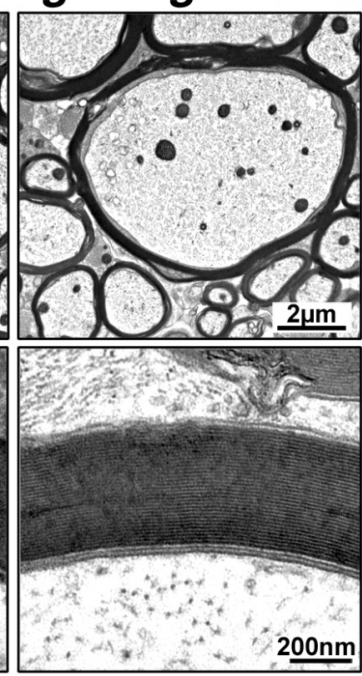

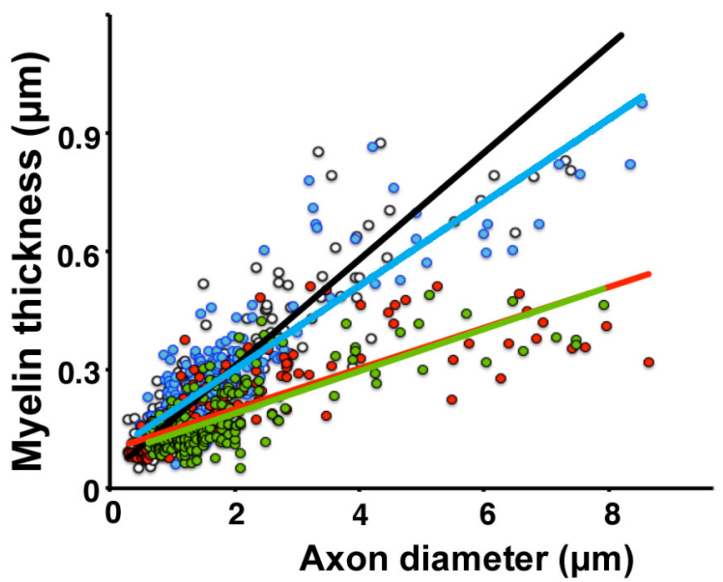

Figure 3. Myelin thickness is reduced in mice lacking Fgfr2 but not Fgfr 1. A, Lower- and higher-magnification EM images taken from similar regions of ventral spinal cords at $5-7$ months from control, Fgfr $1 \mathrm{CKO}$, Fgfr2 CKO, and Fgfr1/Fgfr2 dKO mice show that while the thickness of myelin is similar in the control and Fgfr $1 \mathrm{cKO}$ mice, axons are wrapped by thinner myelin sheaths in Fgfr2 cKO and Fgfr1/Fgfr $2 \mathrm{dKO}$ mice. B, As a measure of myelin thickness, scatter plots of g-ratios (left) and myelin thickness (in micrometers; right) are shown for individual fibers in relation to respective axon diameters, confirming that Fgfr2 $\mathrm{CKO}$ and Fgfr $1 /$ Fgfr2 dKO mice have thinner myelin (higher g-ratios) than Fgfr 1 CKO mice and controls. Approximately 200 axons from two mice of each genotype were analyzed from similar regions of the ventral white matter.

mice the myelin thickness increased in proportion with axon diameter, in the Fgfr $2 c K O$ and $F g f r 1 / F g f r 2 d K O$ mice, axons of all diameters were wrapped by thinner myelin sheaths compared to control and Fgfrl cKO mice (Fig. 3B).

Consistent with the reduction in myelin thickness observed by EM analysis, we found that the MBP-immunolabeled white matter area of the ventral-lateral spinal cords was significantly diminished in the Fgfr2 $c K O$ and Fgfrl/Fgfr2 dKO compared to littermate controls and Fgfr1 cKO mice (Fig. 7; control, $1.41 \pm$ $0.09 \mathrm{~mm}^{2} ;$ Fgfrl $c K O, 1.42 \pm 0.01 \mathrm{~mm}^{2} ; \mathrm{Fgfr} 2 \mathrm{cKO}, 1.04 \pm 0.04$ $\left.\mathrm{mm}^{2} ; \mathrm{Fgfr} 1 / \mathrm{Fgfr} 2 \mathrm{dKO}, 0.93 \pm 0.01 \mathrm{~mm}^{2} ; p<0.01 ; N=3-4\right)$.

Taken together, we conclude that the reduction in myelin gene expression and myelin thickness that was observed in the Fgfr 1/Fgfr 2 dKO was caused by a loss of Fgfr2 but not Fgfrl signaling in oligodendrocytes, suggesting that FGFR2, not FGFR1, is the key FGFR for transducing extracellular signals for myelin growth.

Loss of FGFR2, not FGFR1, results in a downregulation of ERK1/2 activity in oligodendrocytes

By immunoblotting of whole spinal cord homogenates, we showed previously that $\mathrm{p}$-ERK1/2 levels were significantly re- duced in the Fgfr1/Fgfr $2 d K O$ compared to control mice (Furusho et al., 2012), suggesting that ERK1/2 activity, presumably in oligodendrocytes, is regulated by FGFR1, FGFR2, or both. To clarify this issue, we immunolabeled sections of spinal cord at P15 from control, Fgfr1 cKO, Fgfr $2 \mathrm{cKO}$, and Fgfr1/Fgfr2 $d K O$ mice for the expression of p-ERK1/2 and pan-ERK1/2 (Fig. 4A). As expected, we found strong oligodendrocyte-like cellular staining for both p-ERK1/2 and pan-ERK1/2 in the spinal cord white matter of control mice. Immunolabeling for p-ERK1/2 in the Fgfr1 cKO was indistinguishable from that in the control. However, in Fgfr2 $c K O$ and $F g f r 1 / F g f r 2 d K O$ mice, cellular staining of p-ERK1/2 was dramatically downregulated. In parallel sections, cells remained positive for pan-ERK1/2 for all genotypes. To verify that the downregulation of p-ERK1/2 occurred within oligodendrocytes of mice lacking Fgfr2, we double labeled spinal cord sections from control and Fgfr 2 cKO mice for p-ERK1/2 and the oligodendrocyte marker CC1. The observed colocalization of p-ERK1/2 with $\mathrm{CC} 1$ in majority of cells in the control and its virtual absence from CCI+ oligodendrocytes in the white matter of the Fgfr2 $c K O$ mice indicated an oligodendrocyte specific downregulation of ERK1/2 (Fig. 4B). Immunoblotting of white matter from spi- 


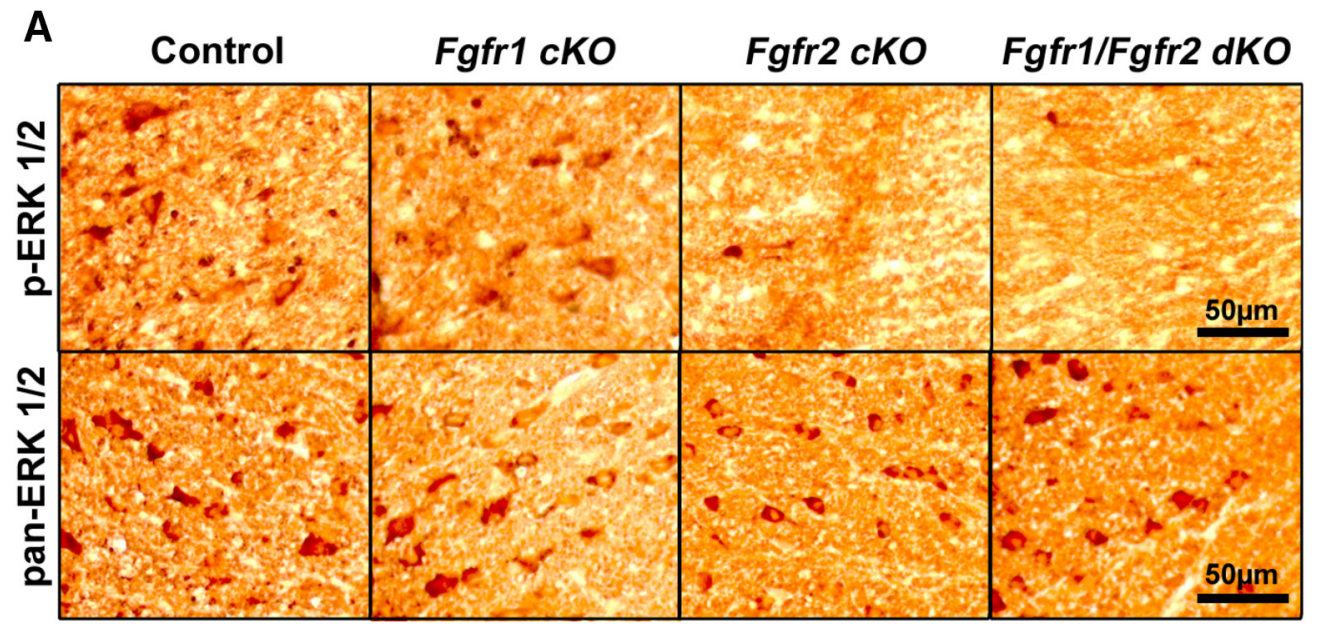

B

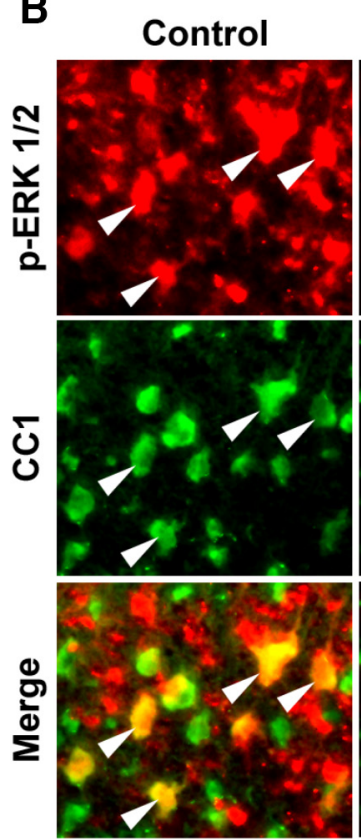

Fgfr2 cKO

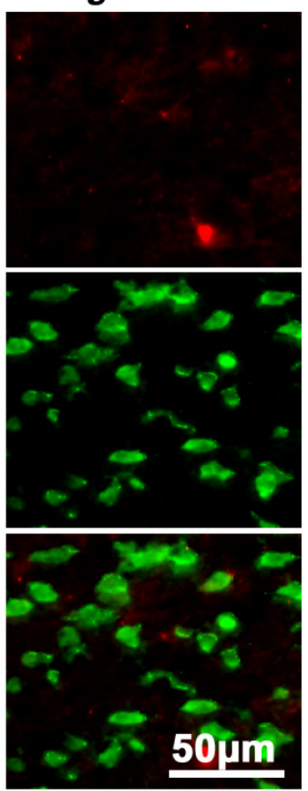

C
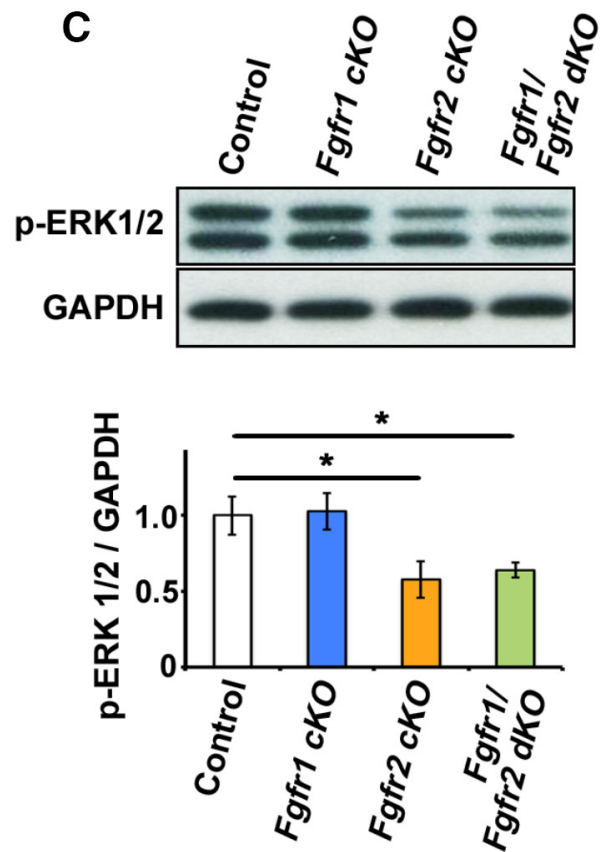

Figure 4. ERK1/2 activity is downregulated in oligodendrocytes in mice lacking Fgfr2 but not Fgfr $1 . A$, Transverse sections of cervical spinal cords at P15, immunolabeled for $p$-ERK1/2 or pan-ERK1/2, show strong oligodendrocyte-like cellular staining in the white matter of control and Fffr $\mathrm{CKO}$ mice, but it is downregulated in Fgfr2 $\mathrm{CKO}$ and $\mathrm{Fgfr} / \mathrm{Fgfr} 2 \mathrm{dKO}$ mice. Parallel sections of spinal cords immunolabeled for pan-ERK1/2 show positive signal in all genotypes. $\boldsymbol{B}$, Double immunolabeling of cervical spinal cord sections from control and $F g f r 2$ CKO mice show presence of p-ERK1/2 signal colocalized with CC 1 in controls (arrowheads) and its virtual absence in $\mathrm{CCl}+$ oligodendrocytes in the matched regions of lateral-ventral white matter of the $\mathrm{Fgfr} 2 \mathrm{CKO}$ mice. $\mathrm{C}$, Immunoblotting of equal amounts of total proteins from homogenates of white matter from spinal cords and quantification of the band intensity on the blots show a statistically significant reduction ofp-ERK1/2 levels in Fgfr2 cKO and Fgfr1/Fgfr 2 dKO but not Fgfr 1 CKO mice compared to control mice. GAPDH, used as a loading control, does not show a change. Three mice from each genotype were analyzed. Error bars represent SEM $(N=3) .{ }^{*} p<0.05$.

nal cords and quantification of the band intensity on the immunoblots confirmed a statistically significant downregulation of p-ERK1/2 in Fgfr $2 c K O$ and $F g f r 1 / F g f r 2 ~ d K O$ but not in Fgfr $1 c K O$ mice (Fig. 4C).

We conclude that the observed downregulation of p-ERK1/2 in the Fgfr 2 cKO and not in the Fgfr 1 cKO is consistent with the hypothesis that FGFR2 and not FGFR1 is the main FGF receptor type in oligodendrocytes that regulates ERK1/2 MAPK activity.

Sustained activation of ERK1/2 in oligodendrocytes is sufficient to rescue the deficit in myelin gene expression and myelin thickness in mice lacking FGFR2

We showed previously that myelin gene expression and myelin thickness were reduced in the ERK1/2 $d K O$ mice (Ishii et al., 2012). Given our observation that a similar phenotype is ob- served in mice lacking Fgfr2, we hypothesized that the arrest of myelin growth in these mice may be due to compromised ERK1/2 signaling. However, this correlative evidence is not sufficient to fully establish a functional link between the two, because several other signaling molecules function downstream of FGFRs, and, conversely, several upstream effectors regulate ERK1/2 activity. Therefore, to provide more conclusive evidence in support of this hypothesis, we asked whether attenuated myelin gene expression and myelin growth in mice lacking Fgfr 2 could be rescued and restored to normal by genetically elevating ERK1/2 activity in oligodendrocytes of these mice. To address this question, we generated transgenic mice that conditionally expressed constitutively active Mek1, an upstream activator of ERK1/2, in mice lacking $F g f r 2$ or Fgfr1/Fgfr2 in oligodendrocytes (referred to as Fgfr2-cKO;Mek/+ or Fgfr1/Fgfr2-dKO;Mek/+, respectively). 

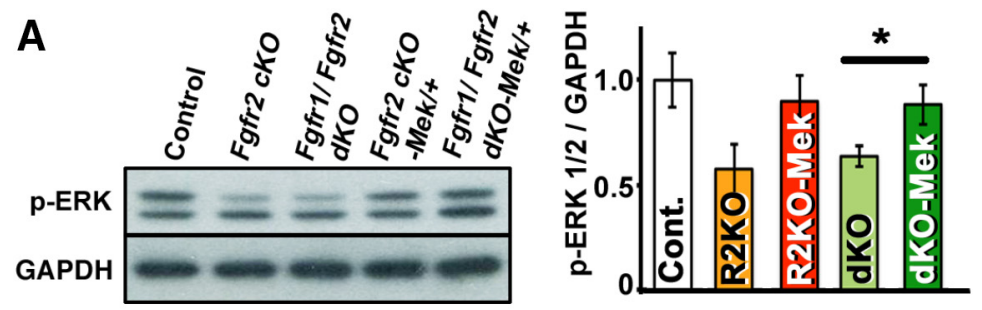

\section{B}

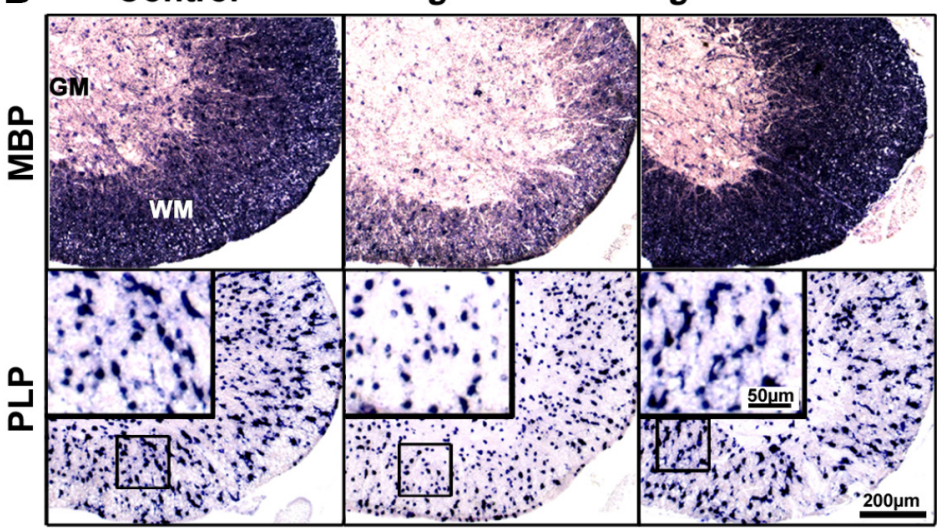

C
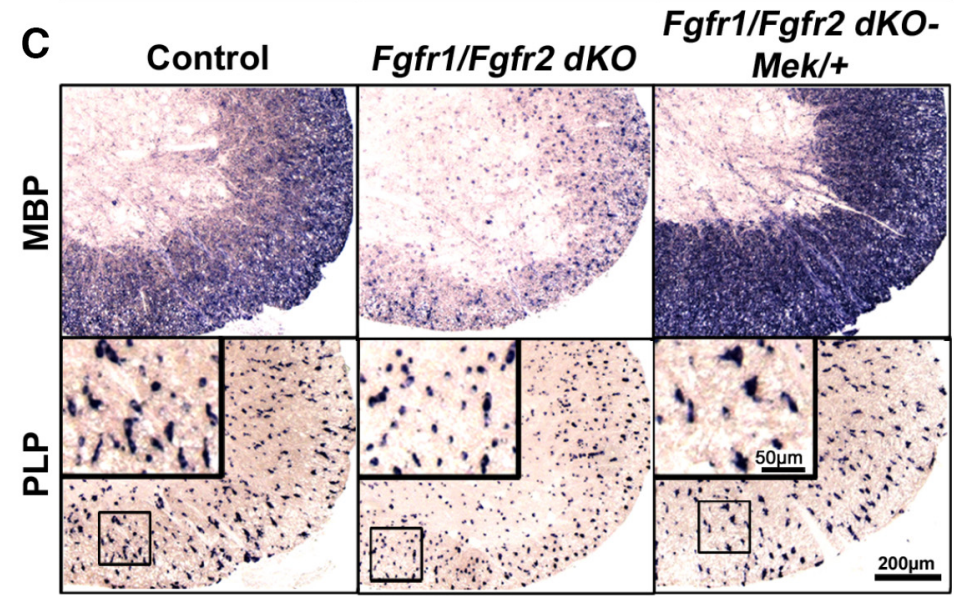

D
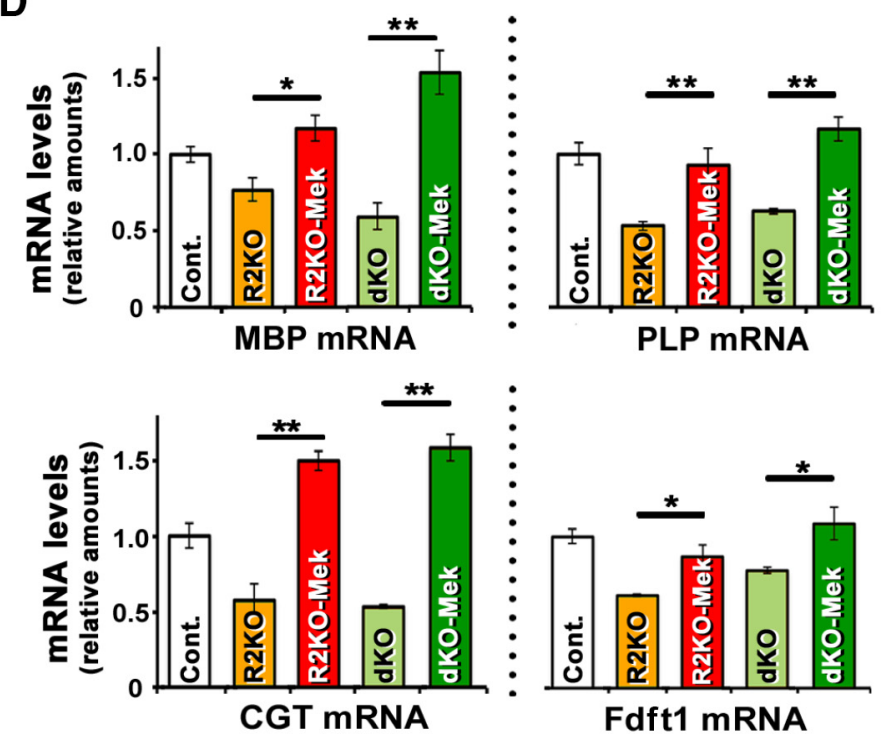

Figure 5. Reduction of myelin gene expression in mice lacking Fgfr2 is rescued by the elevation of ERK1/2 activity in Fgfr2 deficient oligodendrocytes. $\boldsymbol{A}$, Immunoblotting of equal amounts of total proteins from homogenates of spinal cord white matter and quantification of the band intensity on the blots show that compared to controls, p-ERK1/2 levels are reduced in Fgfr2 cKO
We first examined whether p-ERK1/2 expression was upregulated as expected in the Fgfr2-cKO;Mek/+ and Fgfr1/Fgfr2$d K O ; M e k /+$ mice. Immunoblotting of white matter homogenates from spinal cords and quantification of the bands confirmed that p-ERK1/2 levels were upregulated in the Fgfr2-cKO;Mek/+ and Fgfrl/ Fgfr2-dKO;Mek/+ mice compared to the Fgfr $2 \mathrm{CKO}$ and Fgfr1/Fgfr2 dKO mice, respectively (Fig. 5A).

To examine whether ERK1/2 activation would rescue the downregulated myelin gene expression in mice lacking Fgfr 2 , we analyzed transverse sections of cervical spinal cord for the expression of MBP and PLP mRNA by in situ hybridization (Fig. $5 B, C)$. We found that the reduction in the signal intensities of MBP and PLP mRNA observed in transverse sections of cervical spinal cord of Fgfr 2 cKO mice was completely rescued in the $\mathrm{Fgfr} 2-\mathrm{cKO} ; \mathrm{Mek} /+$ mice. Similarly, the reduction of these mRNAs observed in the Fgfr1/Fgfr2 dKO was rescued in the Fgfrl/Fgfr2-dKO; $M e k /+$ mice. Quantification of mRNA levels in the spinal cords by qRT-PCR showed that MBP, PLP, CGT, and Fdft1 (fatty acid chain-synthesizing enzyme) mRNAs were downregulated compared to controls in the Fgfr2 cKO and Fgfr1/ $\mathrm{Fgfr} 2 d K O$ mice and were significantly increased in the Fgfr2-cKO;Mek/+ and Fgfrl/Fgfr2-dKO;Mek/+ mice (Fig. 5D).

We next asked whether elevating the level of ERK1/2 activity in the Fgfr 2 cKO mice would rescue the deficits in myelin thickness (Fig. 6). Low- and highmagnification EM images of ventral spinal cords at 5 months of age showed a reduction of myelin thickness in Fgfr 2 cKO mice compared to control mice. This deficit was restored by the elevation of ERK1/2 activity in the Fgfr2-cKO;Mek/+ mice,

(R2KO) and Fgfr1/Fgfr2 dKO (dKO) mice and are increased to control levels in Fgfr2-KO;Mek/ + (R2KO-Mek) and Fgfr1/Fgfr2 $d K O ; M e k /+$ (dKO-Mek) mice. GAPDH, used as a loading control, does not show a change. $\boldsymbol{B}$, Transverse sections of cervical spinal cord at 1.4 months, analyzed by in situ hybridization for MBP and PLP mRNA, show a reduction in their signal intensity in the Fgfr $2 \mathrm{KO}$ compared to controls, which is increased in the Fgfr2-KO;Mek/+ mice. C, MBP and PLP mRNA levels reduced in Fgfr $1 / \mathrm{Fgfr} 2 \mathrm{dKO}$ are also rescued in $\mathrm{Fgfr} 1 / \mathrm{Fgfr} 2-\mathrm{dKO}$; Mek/+ mice. $\boldsymbol{D}$, Quantification of $m R$ RNA levels by $q R T-P C R$ analysis confirms the downregulation of MBP and PLP mRNA levels in the spinal cords of 1.4-month-old Fgfr2 cKO and Fgfr1/Fgfr2 $d K O$ mice and their statistically significant increase in the Fgfr2-KO;Mek/+ and Fgfr1/Fgfr2-dKO;Mek/+ mice. qRT-PCR analysis of CGT and Fdft1 mRNA in spinal cord in these mice also shows a similar pattern of downregulation and rescue. Error bars indicate SEM. ${ }^{*} p<0.05 ;{ }^{* *} p<0.01 . N=3-4$. WM, White matter; GM, gray matter. 
A

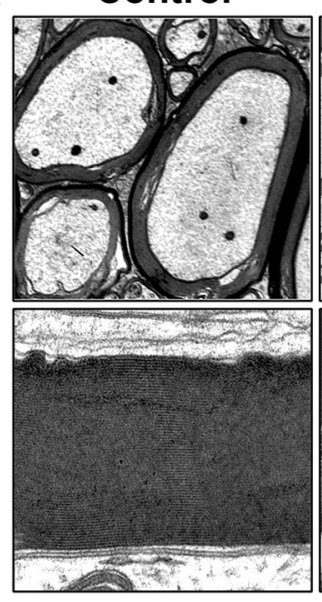

B

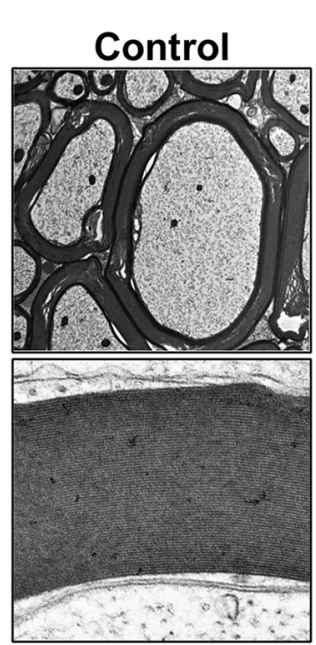

Fgfr2 cKO
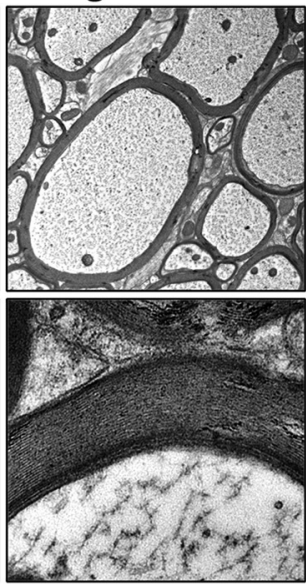

Fgfr1/Fgfr2 dKO
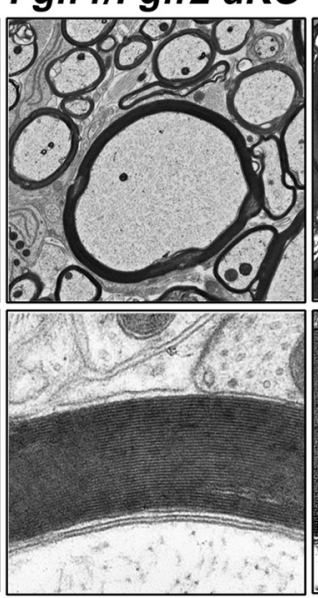

Fgfr2 cKO-Mek/+
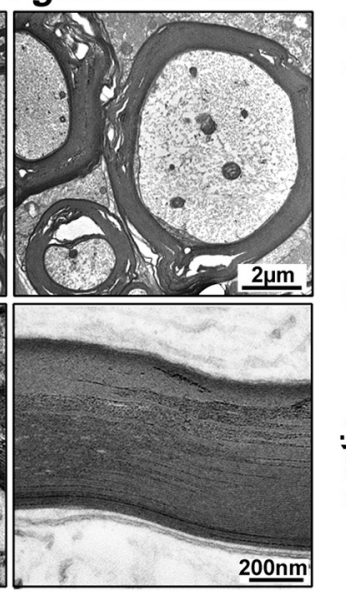

Fgfr1/Fgfr2 dKO-
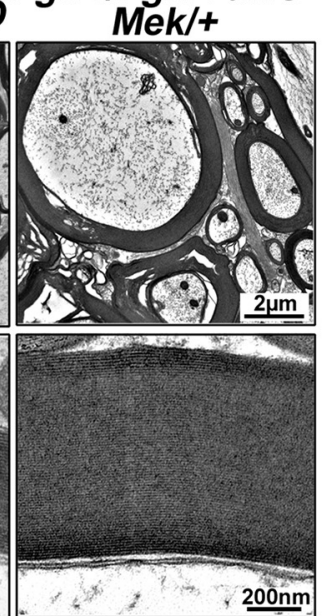
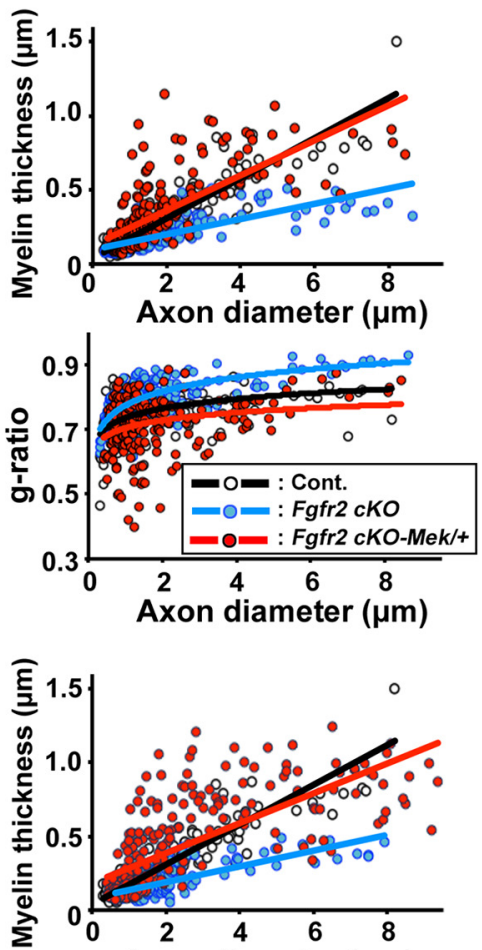

Axon diameter $(\mu \mathrm{m})$

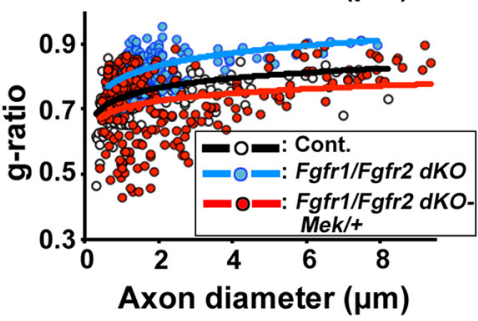

Figure 6. Reduction of myelin sheath thickness in mice lacking Fgfr2 is rescued by the elevation of ERK1/2 activity in Fgfr2-deficient oligodendrocytes. A, EM images taken from similar ventral regions of cervical spinal cords at low and high magnification at 5 months show reduction of myelin thickness in Fgfr2 cKO mice compared to controls and an increase in Fgfr2-KO;Mek/ + mice. As a measure of myelin thickness, scatter plots of $\mathrm{g}$-ratios and myelin thickness (in micrometers) are shown in relation to axon diameters, confirming the rescue of myelin thickness in Fgfr2-K0;Mek/+ mice. $\boldsymbol{B}$, Low- and high-magnification EM images and quantification show a reduction of myelin thickness in Fgfr1/Fgfr2 dKO mice and an increase in Fgfr1/Fgfr2-dKO;Mek/+ mice compared to controls. Approximately 200 axons from 2 mice of each genotype were analyzed from similar regions of the ventral white matter.

which showed thicker myelin sheaths. These observations were confirmed by the quantification of myelin thickness in these mice by the analysis of g-ratios and myelin thickness (in micrometers), showing a significant decrease in the thickness of myelin in the Fgfr2 cKO compared to control and a significant increase in the Fgfr2-cKO; Mek/+ mice (Fig. 6A). Similarly, analysis of EM images and quantification of myelin thickness showed a reduction in Fgfr1/Fgfr2 $\mathrm{dKO}$ compared to control and an increase in Fgfr1/Fgfr2-dKO;Mek/+ mice (Fig. $6 B$; $p$ values for average g-ratios: Fgfr 2 $c K O$ vs Fgfr2-KO; Mek/+, $p=8.4 \times 10^{-22} ; \mathrm{Fgfr} 1 / \mathrm{Fgfr} 2 \mathrm{dKO}$ vs Fgfrl/Fgfr2-dKO; Mek/+, $p=1.8 \times 10^{-30}$ ).

As a further test of this rescue of myelin thickness by ERK1/2 activation in mice deficient in FGFR2 signaling, matched cervical spinal cord sections were immunolabeled for MBP, and the immunolabeled lateral-ventral white matter area was measured (Fig. 7). We found that the reduction observed in the white matter size of Fgfr2 $c K O$ and Fgfr1/Fgfr2 $d K O$ mice was restored to normal in the Fgfr2-cKO;Mek/+ and Fgfr1/Fgfr2-dKO;Mek/+ mice, respectively.

Taken together, these studies provide compelling evidence that ERK1/2 are important intracellular signal transducers re- cruited downstream of the FGFR2 that play a key role in regulating myelin gene expression and myelin growth for the regulation of myelin thickness in the CNS.

FGFR2 signaling regulates the mRNA expression level of the transcription factor Myrf through ERK1/2 activation

We have shown that FGFR2 signaling in mature oligodendrocytes regulates the levels of several major myelin genes at the transcriptional level. It is therefore likely that one or more specific transcription factors that are known to regulate oligodendrocyte lineage cells could be an ultimate target downstream of the FGFR2 signaling cascade. We therefore examined spinal cords from Fgfr 2 cKO mice for the gene expression levels of a panel of transcription factors (Myrf, Zfp191, Nkx6.2, Sox10, Olig2, Olig1, YY1) by qRT-PCR analysis (Fig. 8A). We found that among all of the transcription factors analyzed, only Myrf levels were significantly downregulated in the Fgfr 2 cKO compared to control. Similar analysis of the Fgfr $1 / F g f r 2$ $d K O$ mice also showed a significant downregulation of only Myrf mRNA compared to controls (Fig. 8B).

Given that the downregulation of myelin gene expression in Fgfr 2 cKO and Fgfr1/Fgfr 2 dKO mice could be rescued by genet- 

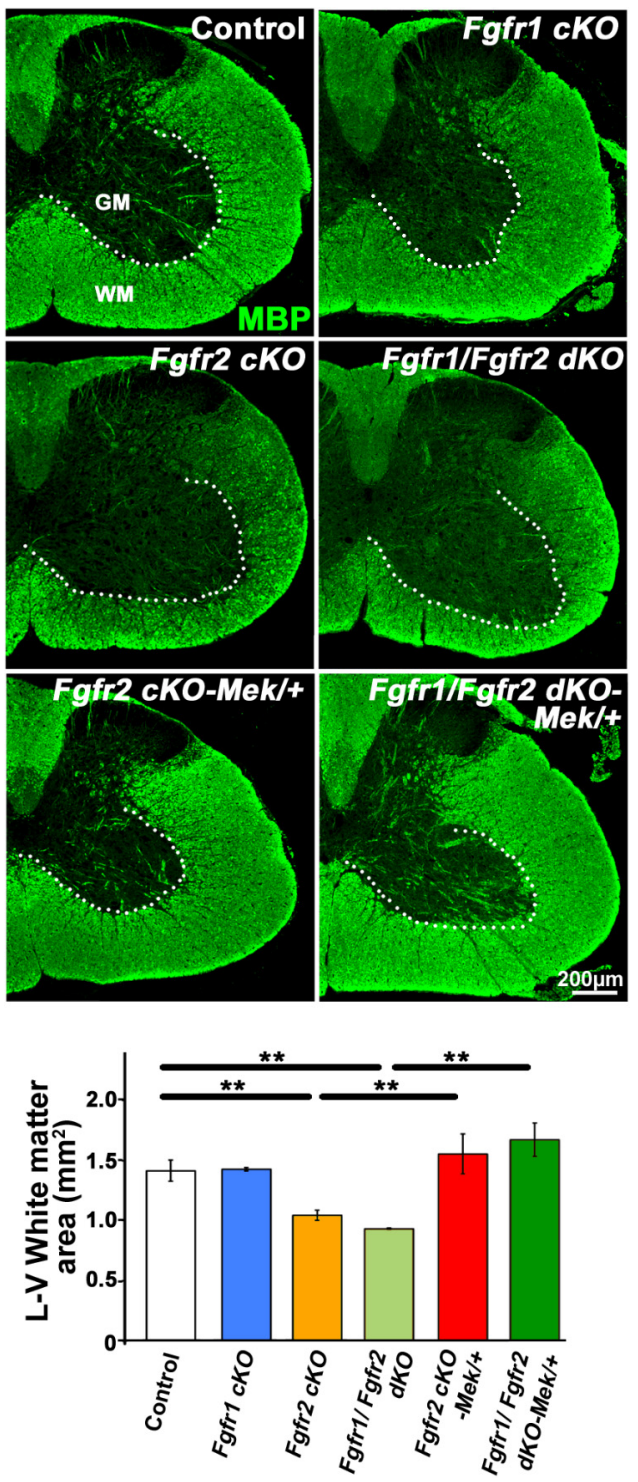

Figure 7. Reduction of white matter size in mice lacking Fgfr2 is rescued by elevation of ERK1/2 activity in Fgfr2-deficient oligodendrocytes. Cervical spinal cord sections from 2-monthold control, Fffr $1 \mathrm{CKO}, \mathrm{Fgfr} 2 \mathrm{CKO}$, and $\mathrm{Fgfr} 1 / 2 \mathrm{dKO}$ mice immunolabeled for MBP show that the size of the MBP + white matter in Fgfr1 $1 K O$ mice is comparable to that in controls, but it is considerably reduced in $\mathrm{Fgfr} 2 \mathrm{CKO}$ and $\mathrm{Fgfr} 1 / \mathrm{Fgfr} 2 \mathrm{dKO}$ mice. The reduction in the white matter area is restored to normal in Fgfr2-K0;Mek/+ and Fgfr1/Fgfr2-dKO;Mek/+ mice. Quantification of the total area of the MBP + lateral-ventral $(L-V)$ white matter confirmed the decrease in

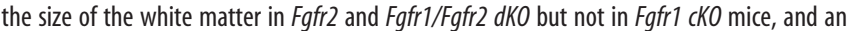
increase in Fgfr2-K0;Mek/+ and Fgfr1/Fgfr2-dK0;Mek/+ mice. Two sections each from two to four mice of each group were analyzed. Error bars represent SEM. $N=2-4 .{ }^{* *} p<0.01 . \mathrm{WM}$, White matter; GM, gray matter.

ically elevating ERK1/2 activity in these mice, we asked whether the downregulated levels of Myrf mRNA could also be rescued in the spinal cords of Fgfr2-cKO;Mek/+ and Fgfr1/Fgfr2-dKO; $M e k /+$ mice. We therefore quantified Myrf mRNA by qRT-PCR analysis and found that its levels were significantly increased in the Fgfrl/Fgfr2-dKO;Mek/+ mice relative to the Fgfrl/Fgfr2 dKO mice. Similarly, the downregulated Myrf mRNA in Fgfr2 cKO also showed a strong trend toward an increase upon ERK1/2 overactivation in the $\mathrm{Fgfr} 2 \mathrm{cKO} ; \mathrm{Mek} /+$ mice, although it did not reach statistical significance (Fig. 8C).

Taken together, we conclude that the mRNA level of the transcription factor Myrf is selectively downregulated in the absence of FGFR2 signaling and is restored to normal by the elevation of ERK1/2 activity in Fgfr2-deficient mice, suggesting that ERK1/2 plays a significant role in transducing the signal downstream of FGFR2 for the regulation of Myrf. This proposed role of ERK1/2 is consistent with our recent findings, which show that genetic loss or gain of ERK1/2 function in transgenic mice results in a corresponding decrease or increase of Myrf mRNA levels both during active myelination and in the adult CNS (Ishii et al., 2014).

FGFR2 and ERK1/2 signaling regulates mTORC1 activity in oligodendrocytes during developmental myelination independently of Akt

Our studies so far strongly indicate that ERK $1 / 2$ is a major downstream target of FGFR2 in the regulation of myelin thickness. However, several other pathways are known to be activated by FGFRs, including the PI3K/Akt/mTOR pathway, which has been suggested to play an equally important role in the regulation of myelin thickness (Narayanan et al., 2009; Goebbels et al., 2010; Harrington et al., 2010; Bercury et al., 2014; Lebrun-Julien et al., 2014; Wahl et al., 2014). We therefore asked whether the loss of FGFR2 would affect the expression of key signaling molecules in the PI3K/Akt/mTOR pathway. To address this question, we immunolabeled spinal cord sections from control, Fgfr $2 c K O$, and Fgfrl/ Fgfr $2 d K O$ mice for the expression of $\mathrm{p}-\mathrm{Akt}{ }^{\mathrm{T} 308}, \mathrm{p}-\mathrm{mTOR}^{\mathrm{S2448}}$, $\mathrm{p}$-Raptor ${ }^{\mathrm{S696}}$, and p-S6RP ${ }^{\mathrm{S} 235 / 5236}$ (Fig. 9A). As shown in Figure 4, the cellular staining of p-ERK1/2 was downregulated in the spinal cord white matter of mice lacking $\mathrm{Fg} f \mathrm{r} 2$ or $\mathrm{Fg} f \mathrm{r} 1 / \mathrm{Fg} f \mathrm{r} 2$. This was completely restored in the Fgfr2-cKO;Mek/+ and Fgfrl/Fgfr2-dKO;Mek/+ mice. In contrast, the $\mathrm{p}-\mathrm{Akt}^{\mathrm{T} 308}$ signal did not show a noticeable reduction in the Fgfr2-deficient mice. However, signal intensities of $\mathrm{p}-\mathrm{mTOR}^{\mathrm{S} 2448}$ and p-Raptor ${ }^{\mathrm{S} 696}$, components of mTORC1, were found to be dramatically reduced in both $\mathrm{Fg} f \mathrm{r} 2 \mathrm{cKO}$ and $\mathrm{Fg} f \mathrm{r} 1 / \mathrm{Fg} f \mathrm{r} 2 \mathrm{dKO}$ compared to control mice. Similarly, p-S6RP ${ }^{\mathrm{S} 235 / 5236}$, a key downstream target of mTORC1, was also reduced in these mutants. To further verify that the reduction in the level of $\mathrm{p}-\mathrm{mTOR}^{\mathrm{S} 2448}$, without a corresponding reduction in the level of $\mathrm{p}-\mathrm{Akt}^{\mathrm{T} 308}$, was occurring within mature oligodendrocytes of mice lacking FGFR2 signaling, we double immunolabeled spinal cord sections from control and Fgfr $2 \mathrm{cKO}$ for $\mathrm{p}-\mathrm{mTOR}^{\mathrm{S} 2448}$ or $\mathrm{p}-\mathrm{Akt}^{\mathrm{T} 308}$ with the mature oligodendrocyte marker CC1 (Fig. 9B). As seen with the DAB staining (Fig. 9A), we found that the $\mathrm{p}-\mathrm{mTOR}^{\mathrm{S} 2448}$ but not $\mathrm{p}-\mathrm{Akt}^{\mathrm{T} 308}$ signal was strikingly reduced in CCI+ oligodendrocytes in the Fgfr $2 \mathrm{cKO}$ mice compared to controls. This was further confirmed by immunoblotting of spinal cord homogenates from control and Fgfr2 cKO mice for $\mathrm{p}-\mathrm{mTOR}^{\mathrm{S} 2448}$ and $\mathrm{p}$-Akt ${ }^{\mathrm{T} 308}$, which showed a statistically significant reduction of $\mathrm{p}-\mathrm{mTOR}^{\mathrm{S} 2448}$ levels in the Fgfr2 cKO compared to control mice, while the levels of $\mathrm{p}$ $\mathrm{Akt}^{\mathrm{T} 308}$ remained unchanged (Fig. 9C).

Given that the expression of $\mathrm{p}-\mathrm{Akt}^{\mathrm{T} 308}$, a classical upstream mediator of mTORC1, remained unaltered in mice lacking Fgfr2, we wondered if the reduction of $\mathrm{p}-\mathrm{mTOR}^{\mathrm{S} 2448}$ was somehow linked to the observed downregulation of p-ERK1/2 in these mice. Therefore, we next asked whether constitutive activation of Mek1 would restore the p-mTOR ${ }^{\text {S2448 }}$ expression levels in these mice. To answer this question, we immunolabeled spinal cord sections from control, Fgfr2-cKO;Mek/+, and Fgfr1/Fgfr2-dKO; $M e k /+$ mice for $\mathrm{p}-\mathrm{Akt}^{\mathrm{T} 308}, \mathrm{p}-\mathrm{mTOR}^{\mathrm{S} 2448}$, $\mathrm{p}$-Raptor ${ }^{\mathrm{S696}}$, and $\mathrm{p}-\mathrm{S} 6 \mathrm{RP}^{\mathrm{S} 235 / \mathrm{S} 236}$ and compared them to parallel sections from the Fgfr2 $c K O$ and Fgfrl/Fgfr2 dKO mice. We found that while p-Akt ${ }^{\mathrm{T} 308}$ staining intensity still remained unchanged, p-mTOR ${ }^{\mathrm{S} 2448}$, p-Raptor $^{\mathrm{S} 696}$, and $\mathrm{p}-\mathrm{S} 6 \mathrm{RP}^{\mathrm{S} 235 / \mathrm{S} 236}$ expression levels were restored to normal in the Fgfr2-cKO;Mek/+ and Fgfrll Fgfr2-dKO;Mek/+ mice (Fig. 9A). This was further confirmed by 
A Fgfr2 cKO

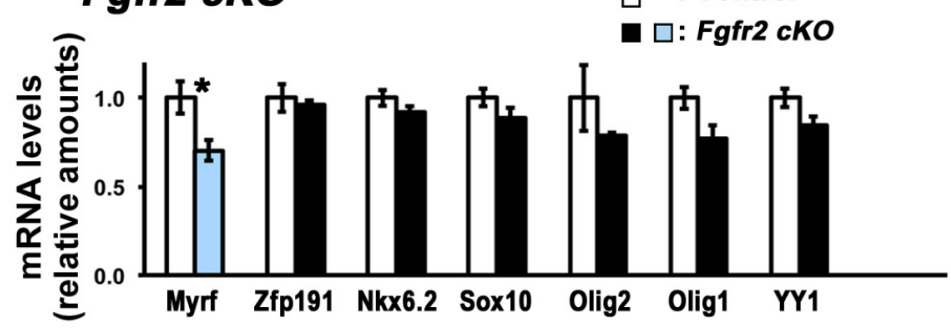

B Fgfr1/Fgfr2 dKO

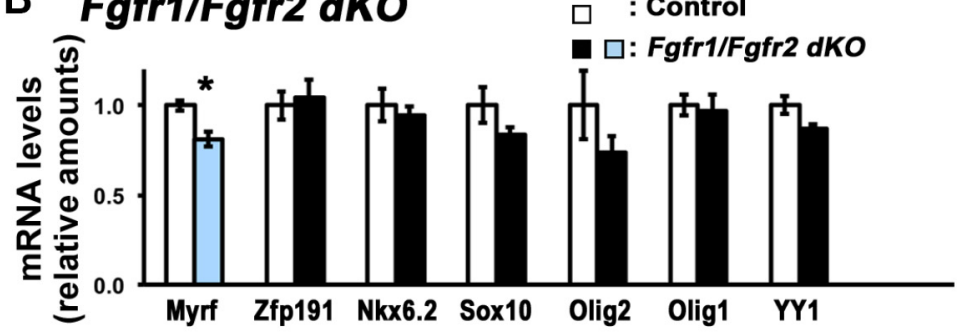

C

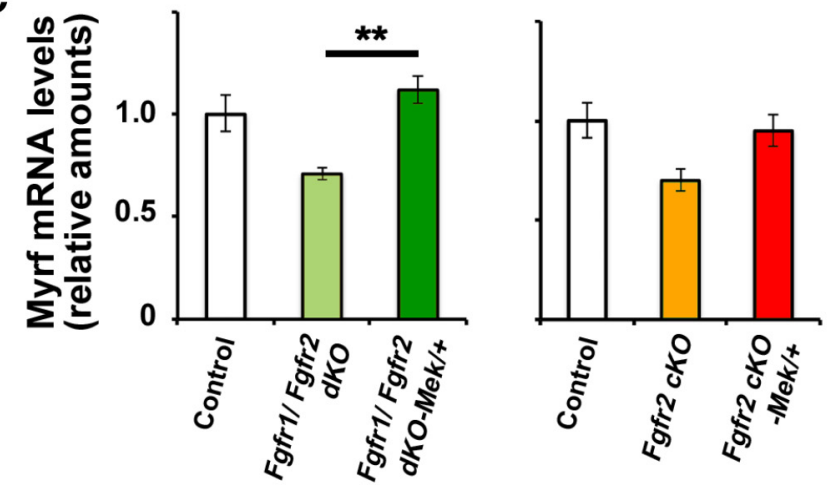

Figure 8. MyrfmRNA is selectively reduced in mice lacking $F g f r 2$ and is rescued by elevation of ERK1/2 activity in Fgfr2-deficient oligodendrocytes. $A, B, q R T-P C R$ analysis of adult spinal cords at P15 shows significant downregulation of Myrf mRNA levels (blue bars) in Fgfr2 cKO (A) and Fgfr1/Fgfr2 dKO (B) mice compared to control mice. In contrast, Zfp191, Nkx6.2, Sox10, 0lig2, Olig1, and YY1 mRNA levels (black bars) show no significant reduction. C, qRT-PCR analysis of spinal cords shows that the reduction in Myrf mRNA in Fgfr2 CKO and Fgfr 1/Fgfr2 dKO mice is rescued in Fgfr2-KO;Mek/+ and Fgfr1/Fgfr2-dKO;Mek/+ mice, respectively. Error bars indicate SEM. ${ }^{*} p<0.05 ;{ }^{* *} p<0.01 . N=3-4$.

immunoblotting of spinal cord homogenates from control, Fgfr2 $c K O$, and Fgfr2-cKO;Mek/+ mice for p-mTOR ${ }^{\mathrm{S} 2448}$ and p-Akt ${ }^{\mathrm{T} 308}$ (Fig. 9C). We found that, consistent with the immunolabeling results, the reduction of $\mathrm{p}-\mathrm{mTOR}^{\mathrm{S} 2448}$ levels in Fgfr 2 cKO mice was restored to normal in the Fgfr2-cKO;Mek/+ mice. In contrast, the levels of $\mathrm{p}-\mathrm{Akt}^{\mathrm{T} 308}$ did not show a significant change in these mice, also consistent with the immunolabeling results. There is a formal possibility that the observed effects on the pathway markers may be in different oligodendrocytes; however, given that ERK1/2 expression is affected in a majority of oligodendrocytes in the conditional Fgfr2-KO;Mek/+ mice, our data are consistent with the notion that FGFR2 plays an important role in the regulation of $\mathrm{mTORC1}$ signaling, most likely through its regulation of $\mathrm{p}$-ERK1/2 within the same oligodendrocytes.

To investigate this intersection of the Mek1/ERK1/2-MAPK and $\mathrm{PI} 3 \mathrm{~K} / \mathrm{Akt} / \mathrm{mTOR}$ pathways in a more direct manner, we next examined the $E R K 1 / 2 \mathrm{dKO}$ mice for potential alterations in the expression of these signaling molecules in the PI3K/Akt/mTOR pathway (Fig. 10). It is known from studies, largely in cell lines, that ERK1/2 can impinge on the PI3K/Akt/mTOR pathway at various levels to promote mTOR signaling (Mendoza et al., 2011). For example, ERK1/ 2-mediated activation of phosphorylation of Raptor ${ }^{\mathrm{S} 696}$ at this specific phosphorylation site can enhance the activity of mTORC1, accompanied by increased phosphorylation of its downstream target molecule, p-S6RP (Carriere et al., 2011). This provides an ERK1/2-dependent mechanism of S6RP phosphorylation via mTORC1 activation. In addition, ERK $1 / 2$ can also directly phosphorylate P70S6K at T421/S424, which are the ERK1/2-specific phosphorylation sites on P70S6K (Zhang et al., 2001). However, it is not known whether ERK1/2 in oligodendrocytes is operating by one or more of these mechanisms during developmental myelination in vivo. We therefore addressed this question by examining the expression levels of these molecules in mice lacking ERK1/2 signaling (Fig. 10). Spinal cord sections from control and ERK1/2 dKO mice were immunolabeled for the expression of $\mathrm{p}-\mathrm{Akt}^{\mathrm{T} 308}, \mathrm{p}$ mTOR $^{\mathrm{S} 2448}$, p-Raptor ${ }^{\mathrm{S} 696}$, p-S6RP ${ }^{\mathrm{S} 235 / \mathrm{S} 236}$, and $\mathrm{p}-\mathrm{p} 70 \mathrm{~S} 6 \mathrm{~K}^{\mathrm{T} 421 / \mathrm{S} 424}$. We found that the intensity of the cellular staining of $\mathrm{p}$ $\mathrm{mTOR}^{\mathrm{S} 2448}$ in the white matter was strikingly downregulated in the ERK1/2 dKO mice, even though $\mathrm{p}$-Akt ${ }^{\mathrm{T} 308}$ did not show a corresponding reduction in its expression levels. Furthermore, p-Raptor ${ }^{\mathrm{S} 696}$, $\mathrm{p}-\mathrm{S} 6 \mathrm{RP}^{\mathrm{S} 235 / \mathrm{S} 236}$, and p-p70S6K $\mathrm{K}^{\mathrm{T} 421 / \mathrm{S} 424}$ were also downregulated in ERK1/2 dKO compared to control mice (Fig. 10A). To verify that the reduction in the level of $\mathrm{p}$ mTOR $^{\mathrm{S} 2448}$ observed in the white matter of the spinal cords of ERK1/2 $d K O$ mice was occurring within mature oligodendrocytes, we double immunolabeled spinal cord sections from control and ERK1/2 $d K O$ mice for $\mathrm{p}-\mathrm{mTOR}^{\mathrm{S} 2448}$ and CC1 (Fig. $10 B)$. We found that in the control, the p$\mathrm{mTOR}^{\mathrm{S} 2448}$ signal colocalized with CC1, while in the ERK1/2 $d K O$ mice, it was almost completely lost from $\mathrm{CCI}+$ oligodendrocytes.

We next took a gain-of-function converse approach and asked whether overstimulation of ERK1/2 in oligodendrocytes by constitutive activation of Mek1 would have an impact on the expression of p-mTOR ${ }^{\mathrm{S} 2448}$ during developmental myelination (Fig. 10C). Spinal cord sections from control and CnpCre;Mek/+ mice were immunolabeled for $\mathrm{p}-\mathrm{mTOR}^{\mathrm{S} 2448}$ at $\mathrm{P} 30$. A clear increase in the intensity of the $\mathrm{p}-\mathrm{mTOR}^{\mathrm{S} 2448}$ signal was observed in the transgenic mice compared to the controls. This is also consistent with our recent findings showing that $\mathrm{p}-\mathrm{mTOR}^{\mathrm{S} 2448}$ activity can be upregulated, even in the quiescent oligodendrocytes of the adult CNS by induced overactivation of ERK1/2 in the PlpCre $e^{E R T}$; $M e k /+$ mice during adulthood (Ishii et al., 2016).

Collectively, our studies using a number of conditional genetically modified mice are consistent with a working model where FGFR2 transmits its signal to ERK1/2-MAPK, which propagates it further by regulating $\mathrm{mTORC} 1$ and its key downstream target, S6RP, suggesting that $\mathrm{mTORC1}$ is an important point of convergence between the ERK1/2-MAPK and the P13K/Akt/mTOR pathways in mature oligodendrocytes during developmental myelination (Fig. 10D). 


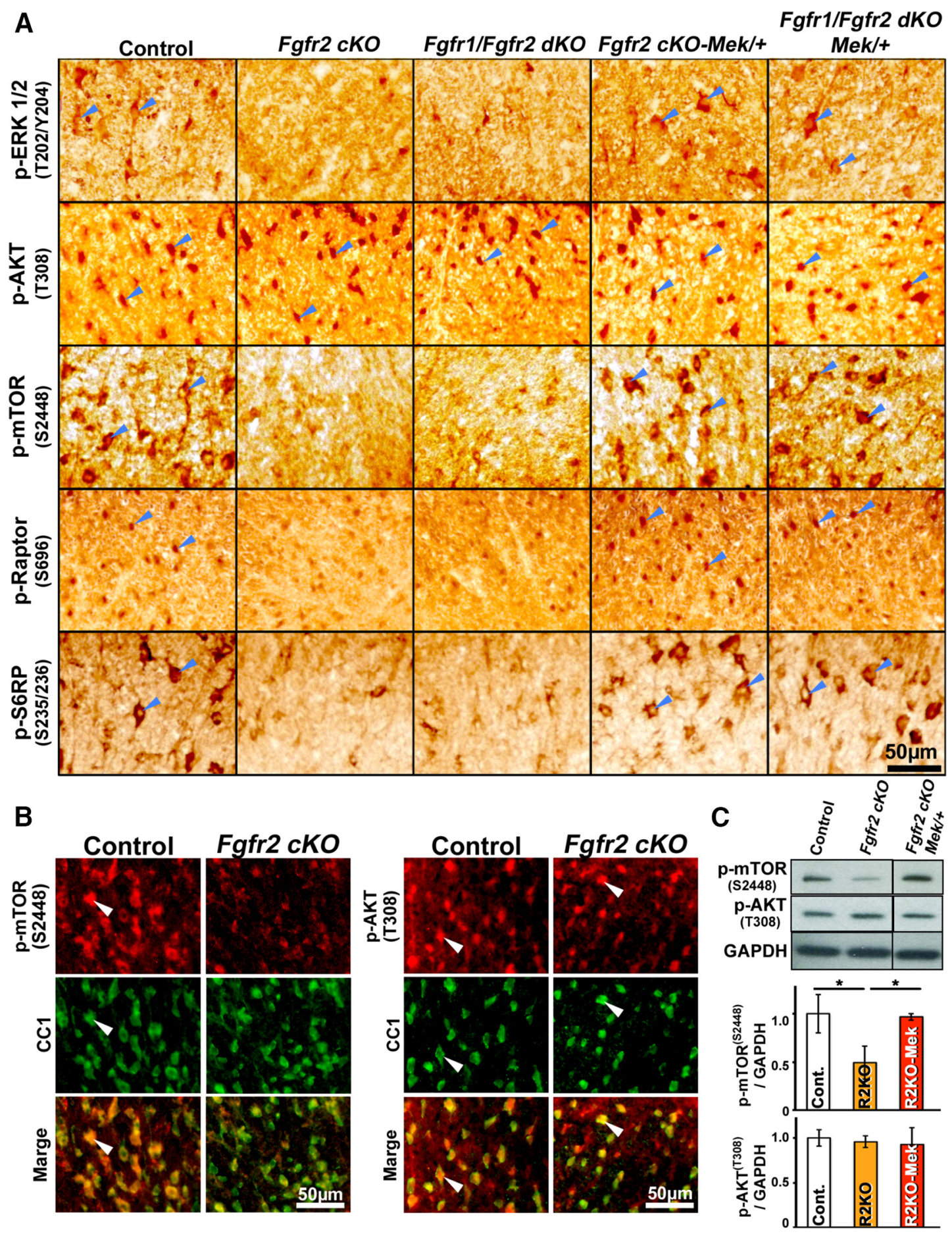

Figure 9. Downregulation of $\mathrm{p}-\mathrm{mTOR}$, $\mathrm{p}$-Raptor, and p-S6RP but not $\mathrm{p}$-Akt in oligodendrocytes of mice lacking $\mathrm{Fgfr} 2$ and recovery upon ERK1/2 activation. $A$, Cervical spinal cord sections from P15 control, Fgfr2 cKO, Fgfr1/Fgfr2 dKO, Fgfr2-KO;Mek/+, and Fgfr1/Fgfr2-dKO;Mek/+ mice analyzed by immunolabeling show that the intensity of cellular staining of p-ERK1/2, mTOR ${ }^{52448}$, p-Raptor ${ }^{5696}$, and p-S6RP ${ }^{5235 / 5236}$ is decreased dramatically in the white matter of Fgfr2 CKO and Fgfr1/Fgfr2 dKO compared to control mice and is restored to normal in Fgfr2-KO;Mek/+ and Fgfr1/Fgfr2-dKO;Mek/+ mice. But, the intensity of the Akt ${ }^{\top 308}$ signal remains largely unchanged in all genotypes. Blue arrowheads point to cellular staining in the spinal cord white matter. $B$, Double immunolabeling of cervical spinal cord sections from control and Fgfr 2 CKO mice for $p$-mTOR ${ }^{52448}$ or p-Akt ${ }^{T 308}$ with the mature oligodendrocyte marker $C_{C C 1}$ shows that the $p$-mTOR ${ }^{52448}$ but not p-Akt ${ }^{\top 308}$ signal is dramatically reduced in CCI + oligodendrocytes in Fgfr2 CKO mice compared to controls (white arrowheads). C, Quantification of mTOR ${ }^{52448}$ and Akt ${ }^{\top 308}$ by immunoblotting of spinal cord white matter at 1.4 months shows a statistically significant reduction of p-mTOR ${ }^{\mathrm{S2448}}$ but not of p-Akt ${ }^{\mathrm{T} 08}$ levels in the Fgfr2 cKO mice compared to controls, which is restored to normal in Fgfr2 $\mathrm{CKO}$; Mek/+ mice. GAPDH is used as a loading control. Error bars represent SEM $(N=3) .{ }^{*} p<0.05$. Representative images from the analysis of at least three animals per genotype, taken from similar regions of lateral-ventral white matter are shown.

\section{Discussion}

In this study, we have shown that conditional ablation of Fgfr2, but not Fgfrl, leads to the downregulation of myelin gene expression and myelin growth, together with the downregulation of
Myrf and p-ERK1/2. More importantly, elevation of ERK1/2 activity in FGFR2-deficient oligodendrocytes rescued these deficits, establishing a strong connection between the two. Finally, the striking finding that mTOR, but not Akt, is downregulated in both the 
A

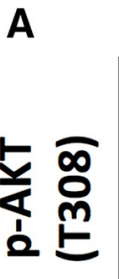

Control
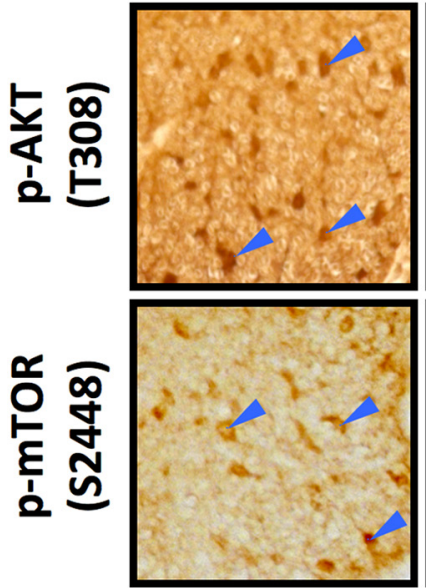

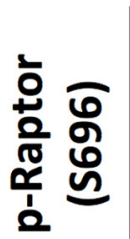

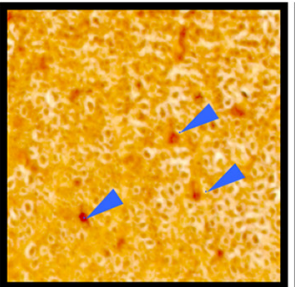

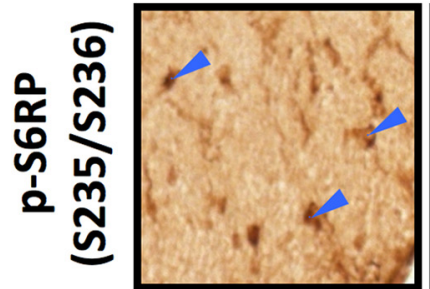
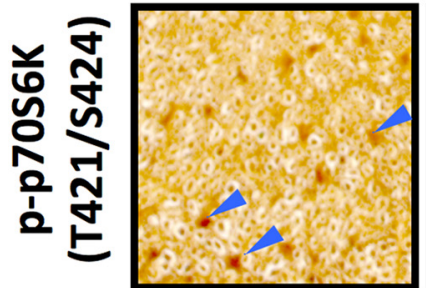

C
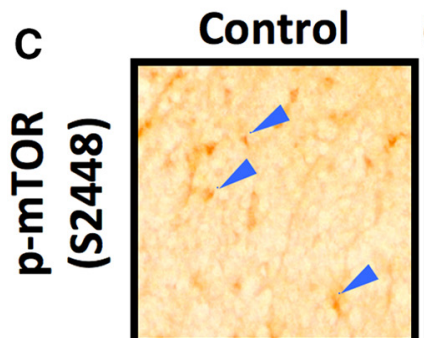
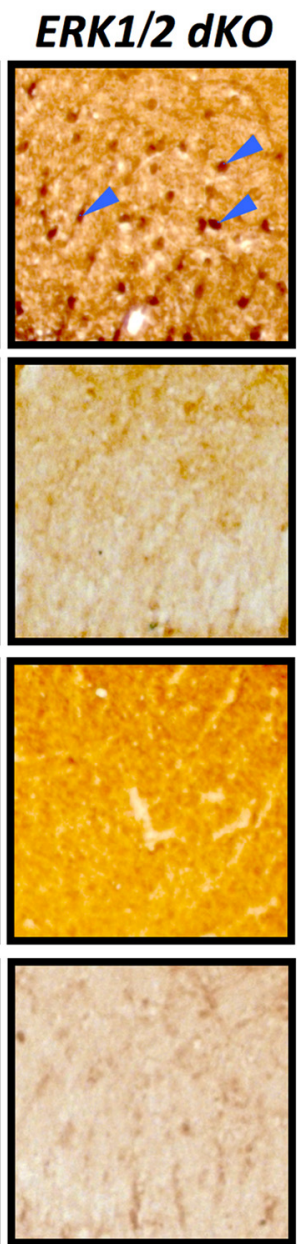

B
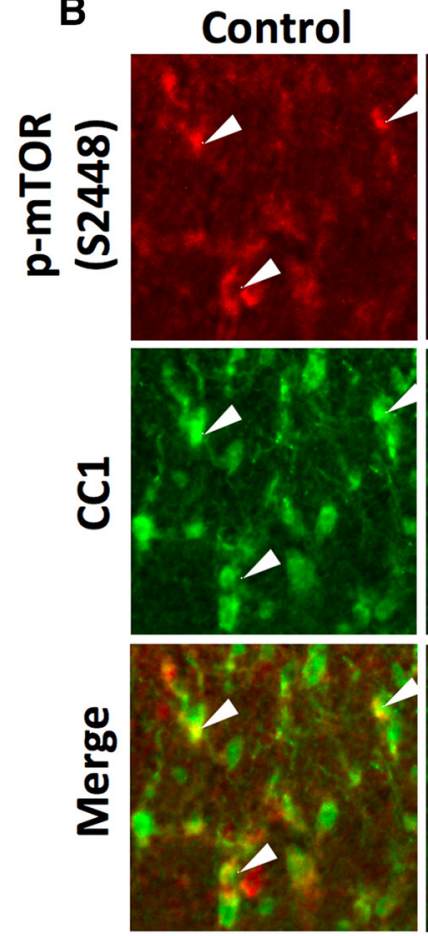

D

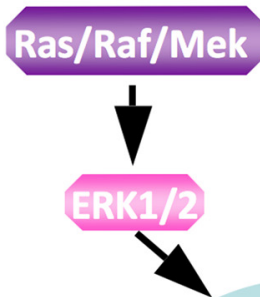

$E R K 1 / 2 d K O$
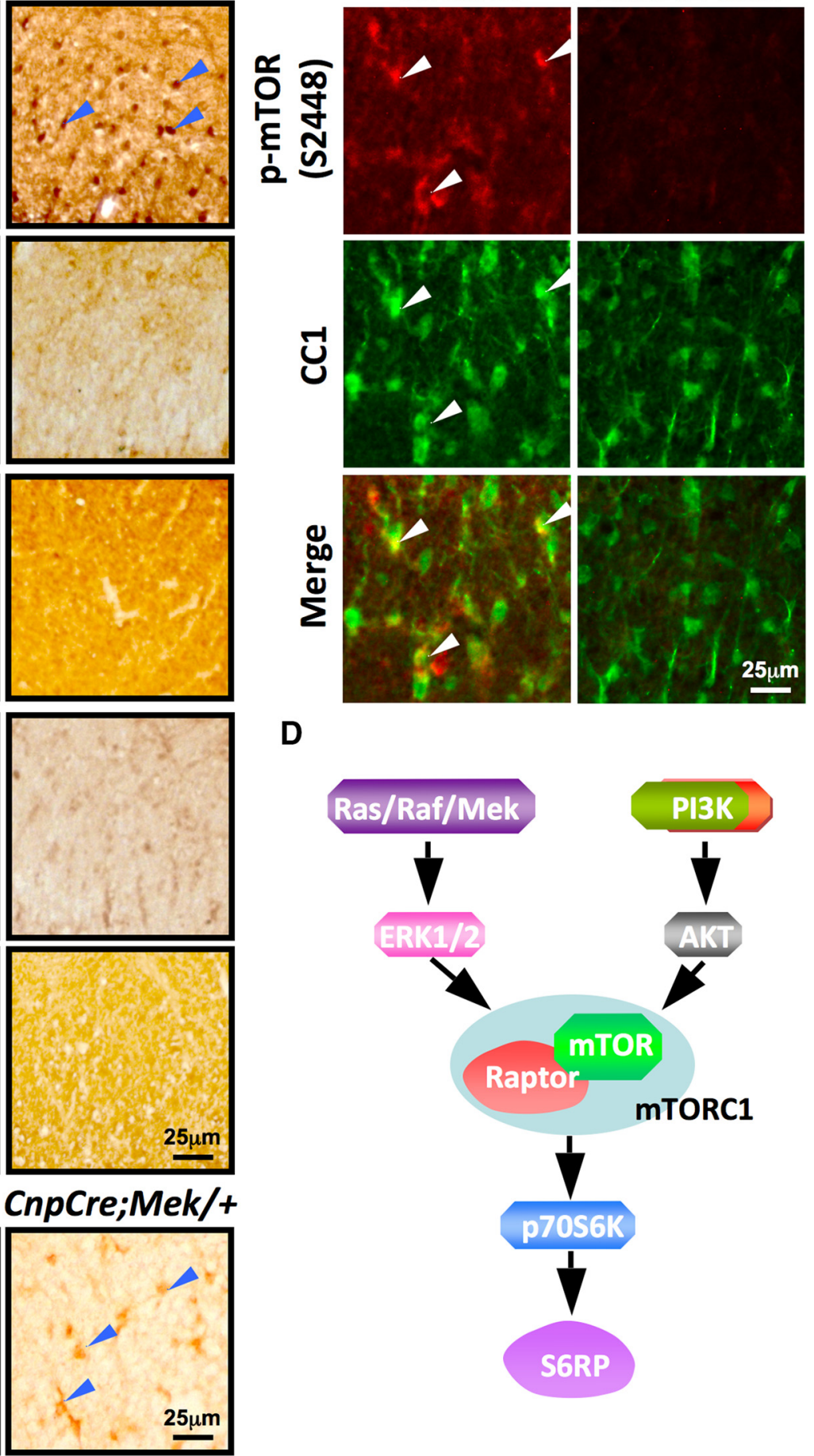

Figure 10. Downregulation of p-mTOR, p-Raptor, p-p70S6K, and p-S6RP but not p-Akt in mice lacking ERK1/2. A, Cervical spinal cord sections from P30 control and ERK1/2 dKO mice analyzed by

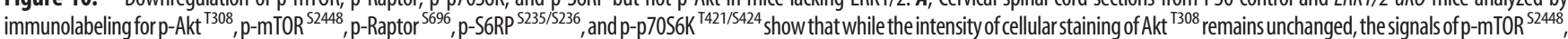

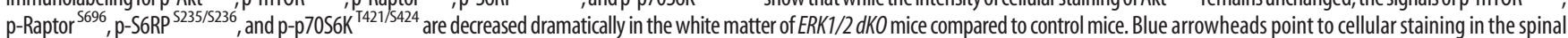
cord white matter. B, Double immunolabeling of cervical spinal cord sections from control and ERK1/2 dKO mice show presence of p-mTOR ${ }^{52448}$ signal colocalized with CC1 in controls (white arrowheads) and its virtual absence in $\mathrm{CCl}+$ oligodendrocytes in the white matter of the ERK1/2 dKO mice. C, Cervical spinal cord sections from control and CnpCre;Mek/+ mice immunolabeled for p-mTOR ${ }^{5248}$ at P30 show cellular staining in the control mice and an increase in the intensity of the signal in CnpCre;Mek/+ mice compared to controls. Representative images from the analysis of at least 3 animals per genotype taken from similar regions of lateral-ventral white matter are shown. Blue arrowheads point to cellular staining in the spinal cord white matter. $\boldsymbol{D}$, Schematic representation of our working model showing convergence between the Mek/ERK1/2-MAPK and the P13K/Akt/mTOR pathways at the level of mTORC1 in mature oligodendrocytes during developmental myelination.

Fgfr 2 cKO and $E R K 1 / 2 d K O$ mice provides a mechanistic framework for understanding how FGFR2-ERK1/2 could regulate translation of myelin proteins through their control on $\mathrm{mTORC1}$ in oligodendrocytes, in addition to regulating their transcription perhaps through the regulation of Myrf, together driving efficient myelin growth during developmental myelination in the CNS.

It is well accepted that myelin is a biologically active membrane receiving and processing signals in bidirectional commu- 
nication with the axons (Bozzali and Wrabetz 2004; Nave 2010) and that myelin gene expression is significantly modulated by axons (Macklin et al., 1986; Kidd et al., 1990; Scherer et al., 1992). However, the axonal signal, the receptors on myelin, and the intracellular mechanisms that regulate myelin gene expression and myelin growth are poorly understood in the CNS. In the PNS, axonal neuregulin-1 provides these signals to ErbB receptors in myelin (Michailov et al., 2004), but it is believed to be dispensable for this function in the CNS (Brinkmann et al., 2008), and IGF-1, which stimulates myelination, is most likely not associated with axons. Our present findings implicating a role of FGFR2 signaling in myelin growth raises the question of whether FGFs presented by the axons signal to FGF receptors in myelin and serve this function in the CNS. The spatial-temporal pattern of FGF and FGF receptor expression is consistent with this notion. Specifically, FGFR2 is abundantly expressed remarkably only upon terminal differentiation of oligodendrocytes (Bansal et al., 1996b; Fortin et al., 2005), and as shown here, it is also expressed in the myelin sheath enriched in the cytoplasmic noncompacted myelin compartments. We also show that two major ligands, FGF1 and FGF2, are expressed in myelinated axons of the normal CNS, consistent with previous immuno-EM and immunohistochemistry studies (Elde et al., 1991; Matsuyama et al., 1992). Furthermore, biochemical studies identified bioactive FGF1 as a key component of axolemma purified from adult myelinated axons (Becker-Catania et al., 2011). Release of growth factors from the axons has been demonstrated previously, at least in vitro (Esper and Loeb 2004; Dean et al., 2012). FGF1 and FGF2 are known to be released in the extracellular space, where they remain sequestered to (or near) the cell surface, bound to heparan sulfate proteoglycan molecules (Mignatti et al., 1992; Salmivirta et al., 1992). Thus, it is plausible that secreted FGFs, bound to the axonal surface, can be presented to FGFR2 in the cytoplasmic compartment of the myelin membrane. Furthermore, p-ERK1/2, a key intracellular target of FGFR2, is also present in this compartment (Ishii et al., 2014). All of this together provides a speculative working model for a role of FGF-FGFR2-ERK1/2 signaling in axon-glia communication, facilitating axon-directed expansion of the myelin sheath during active myelination and perhaps also for its maintenance, as suggested previously for the adult CNS (Ishii et al., 2014).

In vivo studies here show that ablation of FGFR2 but not FGFR1 signaling in oligodendrocytes attenuates myelin gene expression and myelin growth. This finding correlates with our previous in vitro study (Fortin et al., 2005), where we showed that FGF2-induced oligodendrocyte process elongation and myelin-like membrane formation were completely abolished by exposure to anti-FGFR2 but not anti-FGFR1. Collectively, these studies suggest a specific role of FGFR2 but not FGFR1 in transmitting signals for myelin growth. Several plausible reasons can account for this observation. First, it is possible that these receptors could have different signaling specificities, since earlier studies have shown that disruption of signals mediated by ablation of one receptor could not be rescued by another (Deng et al., 1994; Arman et al., 1998). A potential mechanism may involve slight differences in the tyrosine kinase domains or receptors activating the same pathway with different potencies. Second, since FGFR1 is expressed at a lower level than FGFR2 in cultured oligodendrocytes and in the white matter, its loss could have been completely compensated for by the abundantly expressed FGFR2 in the FGFR1 KO (Asai et al., 1993; Miyake et al., 1996; Bansal et al., 2003; Fortin et al., 2005). Third, the observation that FGFR2 but not FGFR1 is present in myelin (Fortin et al., 2005), localized at the paranodal region (present study), could be a significant difference, if FGF signaling in the myelin compartment is important for axon-directed myelin gene expression and myelin growth (discussed in above paragraph). Finally, we reported previously that a significant subfraction of FGFR2, but not FGFR1, resides within cholesterol/glycosphingolipid-enriched membrane microdomains (lipid rafts) in mature oligodendrocytes and purified myelin (Bryant et al., 2009). This spatial segregation of the two receptors could lead to differences in their signaling potential, since it is believed that segregating and concentrating signaling molecules in lipid raft microdomains is an important mechanism for the compartmentalization and enhancement of intracellular signal transduction (Simons and Toomre, 2000). For example, coclustering and activation of FGFR2 within these microdomains with other lipid raft-associated proteins, such as Fyn, NCAM120, integrins, and phospho-FAK (Krämer et al., 1999; Baron et al., 2003, Bryant et al., 2009), could enhance their mutual interactions and signaling potential, as has been seen for plateletderived growth factor receptor-integrin interactions (Baron et al., 2003).

Through the analysis of a series of Fgfr1/Fgfr2 double knockout mice at different stages of myelinogenesis, our previous studies revealed a biphasic requirement of these receptors-first for embryonic induction of oligodendrocyte progenitors (Furusho et al., 2009), and then later for the growth of the myelin sheath during active myelination, but not for proliferation, differentiation, or ensheathment of axons (Furusho et al., 2012). From the analysis of single knock-out mice, we found that for the "earlier function" of oligodendrocyte progenitor induction, cooperation between both FGFR1 and FGFR2 was needed, with FGFR1 being a stronger inducer than FGFR2 (Furusho et al., 2009). It is noteworthy that in the present study, we find that for the "later function" of myelin growth, FGFR2 but not FGFR1 was needed. Thus, these data together suggest that the nature of FGF signaling required for oligodendrocyte progenitor generation from the neuroepithelial precursors and that for myelin biogenesis by mature oligodendrocytes may be interpreted somewhat differently by the cells at different phases of myelinogenesis.

Multiple signal transduction pathways emanating from growth factor receptors often intersect to regulate each other and coregulate downstream functions (Aksamitiene et al., 2012; Mendoza et al., 2011). Interestingly, when we examined the effects of FGFR2 ablation in oligodendrocytes on key downstream signaling molecules in the Ras/Mek/ERK-MAPK and the PI3K/Akt/mTOR pathways, we found a dramatic downregulation of p-ERK1/2, while p-Akt remained largely unchanged in these mice. Surprisingly, the levels of p-mTOR and p-Raptor, key components of mTORC1, traditionally known as downstream effectors in the PI3K/Akt pathway, were dramatically downregulated in these mice and were restored to normal levels upon elevation of ERK1/2 activity in the FGFR2-deficient oligodendrocytes. Furthermore, ERK1/2 KO mice also showed similar downregulation of these molecules. Although ERK1/2-mediated regulation of mTORC1 has been implicated in in vitro studies primarily in cell lines (Carriere et al., 2011), to our knowledge this is the first demonstration of such a regulation by ERK1/2 within differentiated oligodendrocytes and is consistent with the notion that in addition to Akt, ERK1/2 displays a considerable amount of control on mTORC1 and its downstream targets, primarily S6RP, an important regulator of translation. Although these data strongly suggest that mTORC1 is a key point of convergence of the Mek/ ERK/MAPK and PI3K/Akt/mTOR pathways, ERK1/2 are also known to directly phosphorylate and activate p70S6K, a down- 
stream target of mTORC1 (Zhang et al., 2001). Consistent with this, we observed a downregulation of p-p70S6K in oligodendrocytes of the ERK1/2- $d K O$ mice. Furthermore, a transient downregulation of p70S6K phosphorylation was reported in the Erk2-KO mice during remyelination (Michel et al., 2015). Thus, p70S6K and potentially other proteins, such as tuberin (TSC2), may serve as additional sites of convergence. Future studies are expected to further elucidate the mechanisms of "cross talk" between these two important pathways.

In summary, our studies bring up the intriguing possibility that FGFR2 may play an important role in receiving and transmitting signals from FGFs, potentially presented by the axons, for promoting myelin growth. Importantly, we have shown that ERK1/2 MAPK is the primary downstream mediators of this signal, which is propagated further through the involvement of mTORC1 and Myrf. Undoubtedly, additional players will be identified in the future to fill the gaps in our current knowledge about the multiple mechanisms working together to regulate myelin growth in the CNS.

\section{References}

Aksamitiene E, Kiyatkin A, Kholodenko BN (2012) Cross-talk between mitogenic Ras/MAPK and survival PI3K/Akt pathways: a fine balance. Biochem Soc Trans 40:139-146. CrossRef Medline

Arman E, Haffner-Krausz R, Chen Y, Heath JK, Lonai P (1998) Targeted disruption of fibroblast growth factor (FGF) receptor 2 suggests a role for FGF signaling in pregastrulation mammalian development. Proc Natl Acad Sci U S A 95:5082-5087. CrossRef Medline

Asai T, Wanaka A, Kato H, Masana Y, Seo M, Tohyama M (1993) Differential expression of two members of FGF receptor gene family, FGFR-1 and FGFR-2 mRNA, in the adult rat central nervous system. Brain Res Mol Brain Res 17:174-178. CrossRef Medline

Bansal R, Kumar M, Murray K, Pfeiffer SE (1996a) Developmental and FGF-2-mediated regulation of syndecans (1-4) and glypican in oligodendrocytes. Mol Cell Neurosci 7:276-288. CrossRef Medline

Bansal R, Kumar M, Murray K, Morrison RS, Pfeiffer SE (1996b) Regulation of FGF receptors in the oligodendrocyte lineage. Mol Cell Neurosci 7:263-275. CrossRef Medline

Bansal R, Magge S, Winkler S (2003) Specific inhibitor of FGF receptor signaling: FGF-2-mediated effects on proliferation, differentiation, and MAPK activation are inhibited by PD173074 in oligodendrocytelineage cells. J Neurosci Res 74:486-493. CrossRef Medline

Baron W, Decker L, Colognato H, ffrench-Constant C (2003) Regulation of integrin growth factor interactions in oligodendrocytes by lipid raft microdomains. Curr Biol 13:151-155. CrossRef Medline

Becker-Catania SG, Nelson JK, Olivares S, Chen SJ, DeVries GH (2011) Oligodendrocyte progenitor cells proliferate and survive in an immature state following treatment with an axolemma-enriched fraction. ASN Neuro 3:e00053. Medline

Bercury KK, Dai J, Sachs HH, Ahrendsen JT, Wood TL, Macklin WB (2014) Conditional ablation of raptor or rictor has differential impact on oligodendrocyte differentiation and CNS myelination. J Neurosci 34:44664480. CrossRef Medline

Bozzali M, Wrabetz L (2004) Axonal signals and oligodendrocyte differentiation. Neurochem Res 29:979-988. CrossRef Medline

Brewer JR, Mazot P, Soriano P (2016) Genetic insights into the mechanisms of Fgf signaling. Genes Dev 30:751-771. CrossRef Medline

Brinkmann BG, Agarwal A, Sereda MW, Garratt AN, Müller T, Wende H, Stassart RM, Nawaz S, Humml C, Velanac V, Radyushkin K, Goebbels S, Fischer TM, Franklin RJ, Lai C, Ehrenreich H, Birchmeier C, Schwab MH, Nave KA (2008) Neuregulin-1/ErbB signaling serves distinct functions in myelination of the peripheral and central nervous system. Neuron 59:581-595. CrossRef Medline

Bryant MR, Marta CB, Kim FS, Bansal R (2009) Phosphorylation and lipid raft association of fibroblast growth factor receptor-2 in oligodendrocytes. Glia 57:935-946. Medline

Carriere A, Romeo Y, Acosta-Jaquez HA, Moreau J, Bonneil E, Thibault P, Fingar DC, Roux PP (2011) ERK1/2 phosphorylate Raptor to promote Ras-dependent activation of mTOR complex 1 (mTORC1). J Biol Chem 286:567-577. CrossRef Medline
Carson MJ, Behringer RR, Brinster RL, McMorris FA (1993) Insulin-like growth factor I increases brain growth and central nervous system myelination in transgenic mice. Neuron 10:729-740. CrossRef Medline

Cellerino A, Carroll P, Thoenen H, Barde YA (1997) Reduced size of retinal ganglion cell axons and hypomyelination in mice lacking brain-derived neurotrophic factor. Mol Cell Neurosci 9:397-408. CrossRef Medline

Dai J, Bercury KK, Macklin WB (2014) Interaction of mTOR and Erk1/2 signaling to regulate oligodendrocyte differentiation. Glia 62:2096-2109. CrossRef Medline

Dean C, Liu H, Staudt T, Stahlberg MA, Vingill S, Bückers J, Kamin D, Engelhardt J, Jackson MB, Hell SW, Chapman ER (2012) Distinct subsets of Syt-IV/BDNF vesicles are sorted to axons versus dendrites and recruited to synapses by activity. J Neurosci 32:5398-5413. CrossRef Medline

Deng CX, Wynshaw-Boris A, Shen MM, Daugherty C, Ornitz DM, Leder P (1994) Murine FGFR-1 is required for early postimplantation growth and axial organization. Genes Dev 8:3045-3057. CrossRef Medline

D'Ercole AJ, Ye P (2008) Expanding the mind: insulin-like growth factor I and brain development. Endocrinology 149:5958-5962. CrossRef Medline

Dono R (2003) Fibroblast growth factors as regulators of central nervous system development and function. Am J Physiol Regul Integr Comp Physiol 284:R867-R881.

Elde R, Cao YH, Cintra A, Brelje TC, Pelto-Huikko M, Junttila T, Fuxe K, Pettersson RF, Hökfelt T (1991) Prominent expression of acidic fibroblast growth factor in motor and sensory neurons. Neuron 7:349-364. CrossRef Medline

Esper RM, Loeb JA (2004) Rapid axoglial signaling mediated by neuregulin and neurotrophic factors. J Neurosci 24:6218-6227. CrossRef Medline

Fortin D, Rom E, Sun H, Yayon A, Bansal R (2005) Distinct fibroblast growth factor (FGF)/FGF receptor signaling pairs initiate diverse cellular responses in the oligodendrocyte lineage. J Neurosci 25:7470-7479. CrossRef Medline

Furusho M, Dupree JL, Bryant M, Bansal R (2009) Disruption of fibroblast growth factor receptor signaling in nonmyelinating Schwann cells causes sensory axonal neuropathy and impairment of thermal pain sensitivity. J Neurosci 29:1608-1614. CrossRef Medline

Furusho M, Kaga Y, Ishii A, Hébert JM, Bansal R (2011) Fibroblast growth factor signaling is required for the generation of oligodendrocyte progenitors from the embryonic forebrain. J Neurosci 31:5055-5066. CrossRef Medline

Furusho M, Dupree JL, Nave KA, Bansal R (2012) Fibroblast growth factor receptor signaling in oligodendrocytes regulates myelin sheath thickness. J Neurosci 32:6631-6641. CrossRef Medline

Furusho M, Roulois AJ, Franklin RJ, Bansal R (2015) Fibroblast growth factor signaling in oligodendrocyte-lineage cells facilitates recovery of chronically demyelinated lesions but is redundant in acute lesions. Glia 63:1714-1728. CrossRef Medline

Goebbels S, Oltrogge JH, Kemper R, Heilmann I, Bormuth I, Wolfer S, Wichert SP, Möbius W, Liu X, Lappe-Siefke C, Rossner MJ, Groszer M, Suter U, Frahm J, Boretius S, Nave KA (2010) Elevated phosphatidylinositol 3,4,5-trisphosphate in glia triggers cell-autonomous membrane wrapping and myelination. J Neurosci 30:8953-8964. CrossRef Medline

Guardiola-Diaz HM, Ishii A, Bansal R (2012) Erk1/2 MAPK and mTOR signaling sequentially regulates progression through distinct stages of oligodendrocyte differentiation. Glia 60:476-486. CrossRef Medline

Harrington EP, Zhao C, Fancy SP, Kaing S, Franklin RJ, Rowitch DH (2010) Oligodendrocyte PTEN is required for myelin and axonal integrity, not remyelination. Ann Neurol 68:703-716. CrossRef Medline

Ishii A, Fyffe-Maricich SL, Furusho M, Miller RH, Bansal R (2012) ERK1/ ERK2 MAPK signaling is required to increase myelin thickness independent of oligodendrocyte differentiation and initiation of myelination. J Neurosci 32:8855-8864. CrossRef Medline

Ishii A, Furusho M, Bansal R (2013) Sustained activation of ERK1/2 MAPK in oligodendrocytes and Schwann cells enhances myelin growth and stimulates oligodendrocyte progenitor expansion. J Neurosci 33:175-186. CrossRef Medline

Ishii A, Furusho M, Dupree JL, Bansal R (2014) Role of ERK1/2 MAPK signaling in the maintenance of myelin and axonal integrity in the adult CNS. J Neurosci 34:16031-16045. CrossRef Medline

Ishii A, Furusho M, Dupree JL, Bansal R (2016) Strength of ERK1/2 MAPK activation determines its effect on myelin and axonal integrity in the adult CNS. J Neurosci 36:6471-6487. CrossRef Medline 
Jeffries MA, Urbanek K, Torres L, Wendell SG, Rubio ME, Fyffe-Maricich SL (2016) ERK1/2 activation in preexisting oligodendrocytes of adult mice drives new myelin synthesis and enhanced CNS function. J Neurosci 36: 9186-9200. CrossRef Medline

Kaga Y, Shoemaker WJ, Furusho M, Bryant M, Rosenbluth J, Pfeiffer SE, Oh L, Rasband M, Lappe-Siefke C, Yu K, Ornitz DM, Nave KA, Bansal R (2006) Mice with conditional inactivation of fibroblast growth factor receptor-2 signaling in oligodendrocytes have normal myelin but display dramatic hyperactivity when combined with Cnp1 inactivation. J Neurosci 26:12339-12350. CrossRef Medline

Kahn MA, Kumar S, Liebl D, Chang R, Parada LF, De Vellis J (1999) Mice lacking NT-3, and its receptor TrkC, exhibit profound deficiencies in CNS glial cells. Glia 26:153-165. Medline

Kidd GJ, Hauer PE, Trapp BD (1990) Axons modulate myelin protein messenger RNA levels during central nervous system myelination in vivo. J Neurosci Res 26:409-418. CrossRef Medline

Krämer EM, Klein C, Koch T, Boytinck M, Trotter J (1999) Compartmentation of Fyn kinase with glycosylphosphatidylinositol-anchored molecules in oligodendrocytes facilitates kinase activation during myelination. J Biol Chem 274:29042-29049. CrossRef Medline

Lappe-Siefke C, Goebbels S, Gravel M, Nicksch E, Lee J, Braun PE, Griffiths IR, Nave KA (2003) Disruption of Cnp1 uncouples oligodendroglial functions in axonal support and myelination. Nat Genet 33:366-374. CrossRef Medline

Lebrun-Julien F, Bachmann L, Norrmén C, Trötzmüller M, Köfeler H, Rüegg MA, Hall MN, Suter U (2014) Balanced mTORC1 activity in oligodendrocytes is required for accurate CNS myelination. J Neurosci 34:84328448. CrossRef Medline

Macklin WB, Weill CL, Deininger PL (1986) Expression of myelin proteolipid and basic protein mRNAs in cultured cells. J Neurosci Res 16:203217. CrossRef Medline

Matsuyama A, Iwata H, Okumura N, Yoshida S, Imaizumi K, Lee Y, Shiraishi S, Shiosaka S (1992) Localization of basic fibroblast growth factor-like immunoreactivity in the rat brain. Brain Res 587:49-65. CrossRef Medline

Mendoza MC, Er EE, Blenis J (2011) The Ras-ERK and PI3K-mTOR pathways: cross-talk and compensation. Trends Biochem Sci 36:320-328. CrossRef Medline

Menon K, Rasband MN, Taylor CM, Brophy P, Bansal R, Pfeiffer SE (2003) The myelin-axolemmal complex: biochemical dissection and the role of galactosphingolipids. J Neurochem 87:995-1009. Medline

Michailov GV, Sereda MW, Brinkmann BG, Fischer TM, Haug B, Birchmeier C, Role L, Lai C, Schwab MH, Nave KA (2004) Axonal neureglin-1 regulates myelin sheath thickness. Science 304:700-703. CrossRef Medline

Michel K, Zhao T, Karl M, Lewis K, Fyffe-Maricich SL (2015) Translational control of myelin basic protein expression by ERK2 MAP kinase regulates timely remyelination in the adult brain. J Neurosci 35:7850-7865. CrossRef Medline

Mignatti P, Morimoto T, Rifkin DB (1992) Basic fibroblast growth factor, a protein devoid of secretory signal sequence, is released by cells via a pathway independent of the endoplasmic reticulum-Golgi complex. J Cell Physiol 151:81-93. CrossRef Medline

Miyake A, Hattori Y, Ohta M, Itoh N (1996) Rat oligodendrocytes and astrocytes preferentially express fibroblast growth factor receptor- 2 and -3 mRNAs. J Neurosci Res 45(5):534-541. CrossRef

Narayanan SP, Flores AI, Wang F, Macklin WB (2009) Akt signals through the mammalian target of rapamycin pathway to regulate CNS myelination. J Neurosci 29:6860-6870. CrossRef Medline

Nave KA (2010) Myelination and support of axonal integrity by glia. Nature 468:244-252. CrossRef Medline

Piaton G, Gould RM, LubetzkiC (2010) Axon-oligodendrocyte interactions during developmental myelination, demyelination and repair. J Neurochem 114:1243-1260. Medline
Pirvola U, Ylikoski J, Trokovic R, Hébert JM, McConnell SK, Partanen J (2002) FGFR1 is required for the development of the auditory sensory epithelium. Neuron 35:671-680. CrossRef Medline

Roy K, Murtie JC, El-Khodor BF, Edgar N, Sardi SP, Hooks BM, BenoitMarand M, Chen C, Moore H, O’Donnell P, Brunner D, Corfas G (2007) Loss of erbB signaling in oligodendrocytes alters myelin and dopaminergic function, a potential mechanism for neuropsychiatric disorders. Proc Natl Acad Sci U S A 104:8131-8136. CrossRef Medline

Rubinfeld H, Seger R (2005) The ERK cascade: a prototype of MAPK signaling. Mol Biotechnol 31:151-174. CrossRef Medline

Salmivirta M, Heino J, Jalkanen M (1992) Basic fibroblast growth factorsyndecan complex at cell surface or immobilized to matrix proteins promotes cell growth. J Biol Chem 277:17606-17610. Medline

Scherer SS, Vogelbacker HH, Kamholz J (1992) Axons modulate the expression of proteolipid protein in the CNS. J Neurosci Res 32:138-148. CrossRef Medline

Simons K, Toomre D (2000) Lipid rafts and signal transduction. Nat Rev Mol Cell Biol 1:31-39. Medline

Simons M, Nave KA (2015) Oligodendrocytes: myelination and axonal support. Cold Spring Harb Perspect Biol 8:a020479. CrossRef

Taveggia C, Thaker P, Petrylak A, Caporaso GL, Toews A, Falls DL, Einheber S, Salzer JL (2008) Type III neuregulin-1 promotes oligodendrocyte myelination. Glia 56:284-293. CrossRef Medline

Turner N, Grose R (2010) Fibroblast growth factor signalling: from development to cancer. Nat Rev Cancer 10:116-129. CrossRef Medline

Vondran MW, Clinton-Luke P, Honeywell JZ, Dreyfus CF (2010) $\mathrm{BDNF}+/-$ mice exhibit deficits in oligodendrocyte lineage cells of the basal forebrain. Glia 58:848-856. Medline

Wahl SE, McLane LE, Bercury KK, Macklin WB, Wood TL (2014) Mammalian target of rapamycin promotes oligodendrocyte differentiation, initiation and extent of CNS myelination. J Neurosci 34:4453-4465. CrossRef Medline

Wang SJ, Furusho M, D'Sa C, Kuwada S, Conti L, Morest DK, Bansal R (2009) Inactivation of fibroblast growth factor receptor signaling in myelinating glial cells results in significant loss of adult spiral ganglion neurons accompanied by age-related hearing impairment. J Neurosci Res 87:3428-3437. CrossRef Medline

Wong AW, Xiao J, Kemper D, Kilpatrick TJ, Murray SS (2013) Oligodendroglial expression of TrkB independently regulates myelination and progenitor cell proliferation. J Neurosci 33:4947-4957. CrossRef Medline

Ye P, Li L, Richards RG, DiAugustine RP, D’Ercole AJ (2002) Myelination is altered in insulin-like growth factor-I null mutant mice. J Neurosci 22: 6041-6051. Medline

Yu K, Xu J, Liu Z, Sosic D, Shao J, Olson EN, Towler DA, Ornitz DM (2003) Conditional inactivation of FGF receptor 2 reveals an essential role for FGF signaling in the regulation of osteoblast function and bone growth. Development 130:3063-3074. CrossRef Medline

Zeger M, Popken G, Zhang J, Xuan S, Lu QR, Schwab MH, Nave KA, Rowitch D, D'Ercole AJ, Ye P (2007) Insulin-like growth factor type 1 receptor signaling in the cells of oligodendrocyte lineage is required for normal in vivo oligodendrocyte development and myelination. Glia 55:400-411. CrossRef Medline

Zhang Y, Dong Z, Nomura M, Zhong S, Chen N, Bode AM, Dong Z (2001) Signal transduction pathways involved in phosphorylation and activation of p70S6K following exposure to UVA irradiation. J Biol Chem 276: 20913-20923. CrossRef Medline

Zou Y, Jiang W, Wang J, Li Z, Zhang J, Bu J, Zou J, Zhou L, Yu S, Cui Y, Yang W, Luo L, Lu QR, Liu Y, Chen M, Worley PF, Xiao B (2014) Oligodendrocyte precursor cell-intrinsic effect of Rhebl controls differentiation and mediates mTORC1-dependent myelination in brain. J Neurosci 34: 15764-15778. CrossRef Medline 